Working Paper/Document de travail 2009-23

\title{
Short Changed? The Market's Reaction to the Short Sale Ban of 2008
}

by Louis Gagnon and Jonathan Witmer 
Bank of Canada Working Paper 2009-23

August 2009

\title{
Short Changed? The Market's Reaction to the Short Sale Ban of 2008
}

by

\author{
Louis Gagnon $^{1}$ and Jonathan Witmer ${ }^{2}$ \\ ${ }^{1}$ School of Business \\ Queen's University \\ Kingston, Ontario, Canada K7L 3N6 \\ Igagnon@business.queensu.ca \\ 2Financial Markets Department \\ Bank of Canada \\ Ottawa, Ontario, Canada K1A 0G9 \\ jwitmer@bankofcanada.ca
}

Bank of Canada working papers are theoretical or empirical works-in-progress on subjects in economics and finance. The views expressed in this paper are those of the authors.

No responsibility for them should be attributed to the Bank of Canada. 


\section{Acknowledgements}

We are grateful for financial support from Queen's University's Office of Research Services. We thank Jean-Sébastien Fontaine, Scott Hendry, Stéphane Lavoie, Ingrid Lo, Teodora Paligorova, Adrian Pop and Maxwell Stevenson as well as seminar participants at the Bank of Canada, the International Banking, Economics and Finance Association Conference, and the 2009 INFINITI Conference on International Finance, Trinity College Dublin, for helpful comments. We thank Nicholas Michalski for his research assistance. All remaining errors are our own. 


\begin{abstract}
Do short sales restrictions have an impact on security prices? We address this question in the context of a natural experiment surrounding the short sale ban of 2008 using a comprehensive sample of Canadian stocks cross-listed in the U.S. Among financial stocks, which were singled out by the ban in both countries, we observe a significant increase (74 bps) in the difference between the U.S. share price and the Canadian share price. We also observe an impressive and surprising migration of the trading volume from the U.S. to Canada among financial stocks during the ban. Both price and volume effects are reversed after the ban and neither effect manifests itself among the nonfinancial stocks. Our findings support the view that prices reflect a more optimistic valuation when pessimistic investors are kept out of the market by binding short-sales restrictions (Miller (1977)). Our findings also imply that pessimistic investors were more preponderant in the U.S. than in Canada, which is corroborated by the fact that the short interest ratio for our sample stocks was much larger in the U.S. than in Canada prior to the ban.
\end{abstract}

JEL classification: F30, G01, G18, G20

Bank classification: Financial markets; International topics

\title{
Résumé
}

L’imposition de restrictions sur les ventes de titres à découvert a-t-elle une incidence sur les cours? Les auteurs analysent la question dans le contexte d'une expérience naturelle entourant la courte période durant laquelle le Canada et les États-Unis ont prohibé ces opérations sur les titres financiers en 2008. Ils utilisent à cette fin un vaste échantillon d'actions de sociétés canadiennes inscrites à la cote d'une bourse américaine. Pour la période d'interdiction, ils observent un élargissement considérable (74 points de base) de l'écart des cours des titres financiers entre les deux pays ainsi qu'un déplacement spectaculaire et étonnant du volume des opérations sur ces titres vers le Canada. Les effets de prix et de volume, dont aucun ne se manifeste dans le cas des titres non financiers, s'inversent après la levée de l'interdiction. De tels résultats tendent à confirmer que les cours reflètent un optimisme accru lorsque les investisseurs pessimistes sont tenus en dehors du marché par l'action contraignante d'une restriction des ventes à découvert (Miller, 1977). Ils impliquent également que ces investisseurs prédominaient davantage aux États-Unis, ce que corrobore le fait que, avant le début de la période d'interdiction, la proportion des titres vendus à découvert dans l'échantillon retenu était beaucoup plus élevée dans ce pays qu’au Canada.

Classification JEL : F30, G01, G18, G20

Classification de la Banque : Marchés financiers; Questions internationales 
"The Commission is committed to using every weapon in its arsenal to combat market manipulation that threatens investors and capital markets."

Christopher Cox, Chairman

Securities and Exchange Commission

September 18, 2008

1. Introduction

Beginning on Thursday, September 18, 2008, amidst an unprecedented seize-up in the global credit market place, the U.K.'s Financial Services Authority (FSA), the Securities and Exchange Commission (SEC), and the Ontario Securities Commission (OSC) took the world by surprise by ordering, in close succession, a temporary ban on short sales of shares of designated financial sector companies. This ban was implemented in order to stem "...price declines in the securities of financial institutions unrelated to true price valuations" and to quash the short selling of bank stocks, which was suspected of being one of the root causes of the massive selloff that was underway across the world in this sector. ${ }^{2}$ Before the end of that weekend, three more countries (Australia, Taiwan, and the Netherlands ) had joined in this effort.

The three main causes of the credit market seize-up were: 1) the collapse of Lehman Brothers Holdings Inc., which triggered defaults and write-downs throughout the system, 2) the emergency $\$ 85$ billion rescue of American International Group (AIG) by the U.S. Treasury, and 3) the massive run on money market mutual funds that was triggered when the $\$ 62$ billion Reserve Primary Fund "broke the buck" due to Lehman's bankruptcy earlier that week. ${ }^{3}$

The FSA's ban was imposed on 34 issues; the SEC ban targeted the stocks of 799 domestic and foreign firms, while the OSC's ban prohibited short sales in the shares of 13 firms. ${ }^{4,5}$ The SEC and the OSC bans were ultimately lifted on October 8, 2008, five calendar days after the U.S. House of Representatives passed the Emergency Economic Stabilization Act of 2008, while the FSA ban remained in place until the middle of January 2009.

Did the short sale ban of 2008 have an impact on stock prices? In a study commissioned by the International Securities Lending Association (ISLA), the Alternative Investment Management

\footnotetext{
${ }^{1}$ See "SEC Halts Short Selling of Financial Stocks to Protect Investors and Markets", Washington, D.C., Sept. 19, 2008, http://www.sec.gov/news/press/2008/2008-211.htm.

${ }^{2}$ See "Short sale ban spreads around the globe", Wall Street Journal, September 22, 2008.

${ }^{3}$ See "U.S. Plans Rescue of AIG to Halt Crisis; Central Banks Inject Cash as Credit Dries Up, Wall Street Journal, September 16, 2008.

${ }^{4}$ See Securities Exchange Act of 1934 Release No. 34-58592 / September 18, 2008. The U.S. list was ultimately expanded once the SEC granted the exchanges the authority to amend it.

5 The text of the OSC's Original Temporary Order is available on the OSC's website at http://www.osc.gov.on.ca/Enforcement/Proceedings/RAD/rad_20080919_cert-fin-sect-issuers.pdf.
} 
Association (AIMA), and London Investment Banking Association (LIBA), Marsh and Niemen (2008) compare the distributional properties of returns (skewness, kurtosis, and autocorrelations) of stocks subjected to short-sale restrictions and stocks that were not in countries that imposed strong restrictions (U.K and U.S.), countries that imposed weak restrictions (France and Germany), and countries that imposed no restrictions (Sweden and Japan) and find little difference in the behavior of stock returns among the two groups of stocks and across the three groups of countries. In an opinion editorial published in the Wall Street Journal, Bris (2008) argues that, during the first week of the ban, market liquidity in the 799 stocks targeted by the short sale ban dried up, relative spreads increased significantly, and intra-day price ranges almost doubled. ${ }^{6}$ Finally, in an analysis of surveillance data, the Investment Industry Regulatory Organization of Canada (IIROC) finds: 1) No evidence of a reduction in trading volume in restricted financial stocks but evidence of a reduction in the number of trades, 2) No appreciable impact on the price of restricted or unrestricted stocks, as well as 3) A general increase in the volatility for both groups of securities. ${ }^{7}$

Since it targeted a specific subset of stocks, i.e. the stocks of financial companies, the short sale ban of 2008 creates a natural experimental setting in which to assess the impact of short sales restrictions on asset prices. In this paper, we exploit this natural experimental setting in order to shed light on two important questions that are still the object of considerable debate: 1) Do short sales restrictions have an impact on stock prices? 2) Do short sales restrictions impede market efficiency? We tackle these questions from the perspective of Canadian stocks that are cross-listed in the U.S. equity market. Since the two groups of stocks trade in each market concurrently and represent an identical claim on the cashflows of the issuing firm, this empirical setting enables us to tease out the impact of the short sale ban on asset prices by comparing, ceteris paribus, the trading attributes of a treatment group of stocks, i.e. financial stocks, which were subjected to a short selling ban in both markets concurrently, to the trading attributes of a control group of stocks, i.e. non-financials, which were not subjected to a short selling ban. Specifically, we examine the behavior of price differentials (i.e. "arbitrage" spreads) across the two markets, as well as the volatility of these price differentials, the stock pairs' relative bid-ask spreads, and the share of trading volume captured by each market around the short selling ban (i.e. before, during, and after the ban). Since the short sale ban of 2008 came as a complete surprise to all market participants and was imposed by the regulatory authorities in the two jurisdictions on the same group of stocks during the

\footnotetext{
${ }^{6}$ Arturo Bris, "Shorting financial stocks should resume", Wall Street Journal, September 29, 2008. See also "Maybe short-selling is not so bad", New York Times, September 28, 2008.

7 “Study On The Impact Of The Prohibition On The Short Sale Of Inter-Listed Financial Sector Issuers", IIROC, February 2009.
} 
same time period, endogeneity issues arising in most empirical investigations examining the impact of short sales restrictions on asset prices are minimized in our experimental setting.

Overall, our findings reveal that the short sale ban of 2008 had a significant impact on the trading attributes of our treatment group stocks (i.e. the financials) during the ban which did not manifest itself among our control group stocks. Specifically, while our treatment group stocks were trading at a 6 basis point unconditional average discount in the U.S. in the period preceding the ban, they were trading at a highly statistically significant and economically important 68 basis point premium in the U.S. relative to Canada during the short sale ban. More importantly, this 68 basis point average premium observed during the ban was concentrated on negative U.S. market-return days, using the S\&P 500 index as a proxy for the U.S. market. On positive U.S. market-return days, the arbitrage differentials among our treatment group stocks were not significantly different from zero. During the ban, we also observe a significant migration in trading volume from the U.S. to Canada among our treatment group stocks, which was completely reversed after the ban. No such migration of trading volume is observed among our control group stocks. Since neither the price nor the volume effect experienced by our treatment group stocks during the ban manifested themselves among our control group stocks, we are in a position to attribute these two effects solely to the short sale ban.

Our findings lend support to an international version of Miller's (1997) price optimism model in which the degree of pessimism manifested by investors varies across markets. According to Miller's (1997) model, short sales constraints drive stock prices above their equilibrium value by preventing pessimistic investors from impounding their negative views on the stock price by selling the stock short. In the dual-market setting characterizing the present experiment, an expanded version of this model implies that, under short sales constraints in both venues, a cross-listed stock would trade at a higher price in the market where pessimistic investors are more prevalent and it would trade at a lower price in the market where pessimistic investors are less prevalent. In the absence of short sales constraints, such price differences would naturally be arbitraged away but, in the presence of short sales constraints, arbitrageurs would be deprived of an essential mechanism to exploit the price disparity between the two markets and, ultimately, to bring supply and demand conditions in both markets into alignment. Viewed from this theoretical perspective, the large and positive price gap arising among our treatment stocks on negative U.S.-market return days during the short sale ban implies that pessimistic investors were more preponderant in the U.S. than in Canada at the time. This interpretation is reinforced by the fact that the short interest ratio was much higher in the U.S. than in Canada during our sample period across the two 
groups of stocks (i.e. treatment and control). ${ }^{8}$ Our findings also lend support to an international version of the Bai, Chang, and Wang (2006) model in which short sales are either motivated by allocational or by informational considerations. From this perspective, the price increase that we observe in the U.S. relative to Canada among our treatment group stocks during the ban implies that a greater proportion of short selling activity in U.S. cross listed stocks was driven by allocational, i.e. uninformed investors, than in Canada during our sample period. In summation, our paper contributes to the literature in two important ways. First, by demonstrating, via a natural experiment crafted around cross-listed stocks, that short sales constraints do cause stock prices to trade above their equilibrium value as Miller's (1977) price optimism theory suggests and, second, by showing how critical the ability to conduct short sales is to arbitrageurs as a mechanism to enforce the law of one price across markets. To the best of our knowledge, our paper is the first one that examines the impact short sales restrictions in a controlled experimental setting such as the one presented to us by the short sale ban of 2008 .

In the next section, we provide a summary of the literature examining the impact of short sales restrictions on the pricing efficiency and market quality. In Section 3, we articulate our main testable hypothesis and describe our empirical methodology. In Section 4, we describe our data and report summary statistics. In Section 5, we present our empirical findings and, in Section 6, we offer concluding remarks.

\section{Literature background}

Among regulators, the commonly held belief is that short sales constraints can stabilize markets by reducing opportunities for market manipulation and by curtailing speculative excesses among market participants. This sentiment is echoed by a large majority of CEOs, CFOs, and investor relations professionals contacted in a recent survey of corporate issuers conducted by the Opinion Research Corporation on behalf of NYSE Euronext. ${ }^{9}$ In this survey, almost $60 \%$ of respondents consider short selling to be harmful to their company's stock and to their shareholders, and $75 \%$ of respondents think that short selling should be prohibited in periods of heightened volatility. ${ }^{10}$ This perspective stands in stark contrast with the academic finance and the institutional investors' view that short selling enables

\footnotetext{
${ }^{8}$ The increase in the relative price of our treatment group stocks in the U.S. and the reduction in the supply of shares in the U.S. during the ban also offers support for the notion that demand curves for stocks do slope down (Shleifer, 1986).

"'Short Selling Study: The Views of Corporate Issuers", Opinion Research Corporation, October 17, 2008, http://www.nyse.com/press/1224497730781.html.

${ }^{10}$ Among CEOs, the proportion of respondents considering that short sales are harmful and that they should be banned during periods of high volatility climbs to $73 \%$ and $84 \%$, respectively. The survey also indicates that a large majority of respondents believe that the tick test rule which was eliminated by the enactment of Regulation Sho should be re-instated and that public disclosure of investment managers' short selling activity should be mandated by the SEC.
} 
market participants to enforce the law of one price and to maintain equilibrium in the market (e.g. Fama, 1970; and Ross, 1976). Indeed, short selling is such an essential mechanism for the construction of efficient portfolios and for the replicating strategies that underpin the manufacturing process of options and other derivative instruments (e.g. Markowitz, 1952; and Black and Scholes, 1973), that it is difficult to imagine how any market could function efficiently without allowing its participants to sell short. ${ }^{11}$

A significant body of literature has developed that explores the impact of short sales constraints on asset prices and market efficiency. Miller (1977) argues that the effect of short selling on the supply of shares for a particular stock is analogous to the effect of a bank's lending activities on the supply of money. A sufficient amount of short selling could increase the supply of a security until its price is forced down to its equilibrium value. In the presence of binding short sales constraints, when different investors hold different opinions about the value of a security, more pessimistic investors are kept out of the market and prices reflect the valuation of the most optimistic investors. Under short sales constraints, the greater the divergence of opinion among investors, the higher the market price of the security lies in relation to its true value. ${ }^{12}$ Miller's price optimism model is supported in the equilibrium settings examined by Harrison and Kreps (1978), Figlewski (1981), and Jarrow (1980).

In other models, such as Diamond and Verrecchia (1987), short sales constraints do not give rise to the upward bias in prices predicted by Miller (1977) and other price optimism models, but instead influence the rate at which private information is revealed to the public through observable trading. In Hong and Stein (2003), prices are devoid of bias also in the presence of short sales constraints but the interplay between less-than-rational differentially informed investors facing short sales constraints and risk-neutral arbitrageurs, who do not face short-sales constraints, yields predictions about higher moments of the stock return distribution. This model accords well with the evidence showing that the U.S. market exhibits negative skewness. Bai and Chang (2004) devise a fully rational expectations equilibrium model of the economy in which informed and uninformed utility-maximizing agents trade competitively, and show that short sales restrictions have two competing effects on prices. On the one hand, they drive prices up by undermining market liquidity and, on the other hand, they drive prices down by diminishing the informativeness of market prices. In this framework, the net effect of short sales constraints is a slight upward bias in stock prices. In a similar but more general setting, Bai, Chang, and Wang (2006) propose a model in which investors trade to share risk and to speculate on private information. In this model, limiting short sales driven by risk-sharing simply shifts the demand for the asset upwards and

\footnotetext{
${ }^{11}$ Slater (2008) stresses the benefits of short selling for a broad range of players including retail and institutional investors, broker-dealers, and alternative funds.

${ }^{12}$ Diether, Malloy, and Scherbina (2002) show that dispersion in analysts' earnings forecasts can be viewed as a proxy for differences in opinion among investors.
} 
consequently its price. On the other hand, limiting short sales driven by private information increases the uncertainty about the asset as perceived by less informed investors, thereby reducing their demand for the asset and causing asset prices to decrease and volatility to increase. The net impact of short sales constraints on asset prices depends upon which trading motive dominates the market at any given time.

Abreu and Brunnermeier $(2002,2003)$ and Scheinkman and Xiong (2003) show that short sales constraints can be a direct cause of, or at least a necessary condition for, bubbles and excessive volatility. Allen and Gale (1991) take exception with the main stream and side with the regulators' view that short sales are detrimental to the market by arguing that the potential for financial innovation renders short selling a destabilizing influence in the economy.

The bulk of the empirical evidence on the impact of short sales constraints supports the theoretical proposition that they hinder pricing efficiency. Consistent with Miller's (1977) price optimism model, D'Avolio (2002) finds that the incidence of equity loan market specials is increasing in the divergence of opinions among investors. Using one year of equity loans data provided by a major securities lender, Geczy, Musto, and Reed (2002) find that short sales restrictions have a mixed impact on the profitability of well-known trading strategies that rely on short sales. Using early-20th century U.S data, Jones and Lamont (2002) report findings that are consistent with the hypothesis that difficult-toshort stocks are overpriced. Lamont and Thaler (2003) also present empirical evidence showing that high short-sale costs can lead to lower future returns. Using data on DotComs, Ofek and Richardson (2003) show that short sales restrictions in the form of employee stock option lock-ups have a considerable and persistent negative impact on subsequent stock returns. In a study based on mutual fund holdings, Chen, Hong, and Stein (2002), use "breadth of ownership," i.e. the number of investors with long positions in a particular stock, as a proxy of "the amount of adverse information that was excluded from market price due to short-sales constraints" and find that stocks experiencing a decrease in ownership breadth tend to have high valuations and low subsequent returns. These findings accord well with Miller's (1977) price optimism also.

Danielsen and Sorescu (2001) argue that since exchange-traded put and call options provide a cost effective way to establish a short position in a stock, either by purchasing puts or by selling calls, the introduction of options trading effectively relaxes existing short sales constraints. Their empirical findings indicate that post-1980 option introductions are associated with negative abnormal returns in underlying stocks, which is consistent with the hypothesis that stocks are overvalued in the presence of short-sales constraints. 
Using a sample of countries with time-series as well as cross-sectional differences in short sales practice, Bris, Geotzmann, and Zhu (2007) also find empirical evidence in support of the theoretical proposition that short sales restrictions inhibit downward price discovery but, more surprisingly, their analysis also provides support for the commonly held belief among regulators that short sales restrictions are associated with less negative skewness in market returns.

\section{Methodology and Hypothesis Development}

Our null hypothesis is that short sales restrictions have no economic bearing on the price discovery process in either market nor on the ability of arbitrageurs to maintain the parity between prices of the cross-listed pairs, on an exchange rate adjusted basis. Under this null hypothesis, the SEC-OSC short sale ban of 2008 should have no discernable impact on the cross-listed share prices in the two markets, on the stocks' relative bid-ask spreads, on their trading volume, on the pairs' price differentials across the two markets, and on the distribution of trading activity between the two markets. Furthermore, if short sales restrictions do not matter, we should observe no significant difference in the behavior of price differences and trading volume across the two groups of cross-listed firms, i.e. the short-sale constrained and the unconstrained firms, during the ban. If, on the other hand, the introduction of binding short-selling constraints in the two markets has a significant impact on the process of price discovery within each market and across the two markets, then we expect stock prices, trading volume, and other trading attributes of the short-sale constrained stocks in the two markets to be impacted during the period of the ban. Miller's (1977) price optimism model and Bai and Chang's (2004) model predict an immediate and sustained rise in the price of each short-sale-restricted cross-listed pair and a reversal of this effect after the ban, and no price impact on the unconstrained pairs during the ban. A similar prediction arises under the Bai, Chang, and Wang (2006) model provided that risk-sharing is the dominant trading motive among traders during the ban. Contrastingly, according to the Diamond and Verrecchia (1987) theory, then we would expect no price (nor price differential) reaction for financials during the period of the ban, but we would expect instead a slowdown in the speed at which new information becomes impounded in the prices over time.

The extant theories discussed earlier explore the implications of short sales constraints in a singlemarket setting but we can nonetheless expand these models' theoretical predictions to an international setting which comprises cross-listings and shed light on the impact of the short sale ban on the price differentials of our cross-listed pairs. For instance, if Miller's (1977) price optimism model holds in both countries, we would expect the price differential between the two markets for any given pair to remain unchanged during the short sale ban as long as pessimists have the same weight on prices in the two 
markets. If, on the other hand, the pessimists are more preponderant in one market than in the other, say the U.S. for the sake of the argument, then we should expect the difference between the U.S. price and the Canadian price (on an exchange-rate adjusted basis) to increase as the short sale ban comes into effect. We can also draw predictions from the Bai, Chang, and Wang (2006) model. The impact of the short sale ban will differ according to which trading motive dominates in each market during the ban. If the ratio of allocational-to-informational trading is identical in both countries and remains so during the ban, then we would expect no change in the price differentials during the ban relative to pre- and post-ban. If, on the other hand, the ratio of allocational-to-informational trading is larger in the U.S. and lower in Canada, then an international version of Bai, Chang, and Wang (2006) would predict a rise in the stock's U.S. price and a simultaneous fall in its Canadian price during the ban, which implies a net increase in U.S.Canada price differential between the two markets. If, on the other hand, the ratio of allocational-toinformational trading is larger in Canada than in the U.S., an expanded version of the Bai, Chang, and Wang (2006) model would predict a wedge to arise between the stock's price in the U.S. and in Canada but in the other direction, i.e. the stock would trade at a discount in the U.S. relative to Canada during the short sale ban.

Our formal tests are based on the following panel regression specification:

$$
\begin{aligned}
\text { dep } \operatorname{var}_{i t}=\alpha & +\beta_{1} D_{\text {BAN }, t}+\beta_{2} D_{\text {BAN }, t} \times D_{\text {FINANCIAL }, i}+\beta_{3} D_{\text {POST-BAN }, t} \\
& +\beta_{4} D_{\text {POST-BAN }, t} \times D_{\text {FINANCIAL }, i}+\sum_{\text {Controls }} \beta_{\text {Control }} \text { Control }_{i t}+\mu_{i}+e_{i t}
\end{aligned}
$$

Where $D_{B a n, t}$ is an indicator variable set to one during the short sale ban period and to zero otherwise; $\mathrm{D}_{\text {Financial,i }}$ is an indicator variable set to one if the stock pair corresponds to a Canadian financial institution subjected to the short sale ban and to zero otherwise; $\mathrm{D}_{\text {Post-Ban,t }}$ is an indicator variable set to one during the period after the short sale ban period and to zero otherwise; $\mu_{\mathrm{i}}$ is the firm fixed effect. In this regression, $\beta_{1}$ captures the impact of the short sale ban on the dependent variable for the average nonfinancial cross-listed stock while $\beta_{2}$, the coefficient associated with the product of the two indicator variables, captures the incremental impact of the ban for financial stocks. We examine the impact of the ban on the price differentials, the absolute value of these price differentials, the relative bid-ask spreads in both markets, and the Canadian share of aggregate trading volume. Under the null hypothesis that the short trading ban has no bearing on security prices or market functioning, we hypothesize that the $\beta_{2}$ coefficient from this regression is not significantly different from zero. On the hand, the $\beta_{1}$ coefficient captures any other effect, coinciding with but separate from the ban itself, which influences both groups of stocks, not only those that are subject to the ban. 
Difference-in-difference methods (as in the above regression) rely on the assumption that the price differentials would have exhibited similar patterns over time across financial and non-financial firms had the ban not occurred. Therefore, we include the post-ban indicator variables in equation (1) in order to assess the market's reaction to the termination of the ban. Under the null hypothesis that the short sale ban is irrelevant, the termination of the short selling ban should also be irrelevant. However, even under the alternative hypothesis that the ban had an impact, there should be no difference between financial and non-financial stocks once the ban is over. Therefore, the $\beta_{4}$ coefficient from regression equation (1) should not be significantly different from zero under both the null and alternative hypotheses. If the $\beta_{4}$ coefficient turned out to be non-zero, this would indicate that the effect captured by the $\beta_{2}$ coefficient is not solely driven by the short sale ban but by other factors that may reflect other sources of difference between the treatment group (i.e., financials) and the control group that persisted beyond the termination of the ban.

Since the unprecedented level of uncertainty characterizing the market environment in the period surrounding the short sale ban may exert an influence on the dynamics of the market for cross-listed stocks around the ban period, we also include firm-level and market-level control variables in some specifications. Our firm-level control variables include bid-ask spreads and the daily trading range, which we use as a high-frequency proxy for the stock's volatility. Since fluctuations in the bid-ask spread and in the stock's volatility render arbitrage among the cross-listed pairs more costly or more risky, or both, these proxies control for firm-specific factors that impede arbitrage activity over and above the imposition of the short sale ban. In order to control for market-wide changes in market conditions, we use the U.S. equity market volatility index (VIX) and the 1-month USD-CAD volatility index series. In some specifications, we include a time indicator to capture market-wide influences on the trading attributes of interest.

\section{Sample and Descriptive Statistics}

A. Sample

Our sample selection begins by drawing, from Bloomberg, the complete list of Canadian firms that had common shares listed simultaneously on the Toronto Stock exchange and on one of the three U.S. exchanges (New York Stock Exchange, the American Stock Exchange, and NASDAQ) on July 9, 2008. At the outset, the list includes 178 cross-listed firms. We obtain daily bid, ask, low, high, volume, and closing price series for each cross-listed pair from Bloomberg for the period beginning on January 1 , 2008 and ending on November 30th, 2008. We exclude days when either market is closed or has closed earlier than the other market. All prices are expressed in U.S. dollars using the exchange rate prevailing at 
the end of the trading day in the U.S. ${ }^{13}$ Our sample period encompasses the short sale ban in the shares of all U.S. listed financial firms starting on September 19, 2008, and ending on October 8, 2008, which is the main focus of this study. We eliminate 14 firms for which price observations are missing throughout the entire sample period either in Canada or in the U.S. In order to narrow our focus on large, visible, liquid, actively traded, and more arbitrageable Canadian cross-listed pairs, we exclude from our sample all stocks trading at or below $\$ 5$ at any point in time during our sample period. ${ }^{14}$ Our final sample consists of a total of 55 Canadian cross-listed firms, including 8 financial firms, which were subjected to the SECOSC short sale ban, and 47 non-financial firms, which were not subjected to this prohibition. ${ }^{15}$ We also extract the S\&P 500, the S\&P/TSX, and the VIX index as well as the USD-CAD 1 month volatility index series also from Bloomberg.

\section{B. Summary Statistics}

Figure 1 shows the average price series for the financial and for the non-financial stocks on Canadian and U.S. exchanges during our sample period, using January 4, 2008, as the base price for each stock price series, in order to facilitate comparisons between the two groups and across the two markets. From the beginning of the 2008 through to the end of November, both groups of firms lost close to $50 \%$ of their value. For both groups, the average price series across Canada and the U.S. appear to be closely synchronized. This is expected given the presence of arbitrageurs presumably exploiting profitable price disparities arising within pairs across the two markets. The shaded area indicates the period during which the short sale ban was imposed on financial stocks in both countries. Upon the announcement of the ban, we notice a clear run up in the market value of both groups of stocks, which implies the arrival of positive news at the time impacting not only the financial sector but the overall economy as well. It is difficult to pin-point a specific cause for this market-wide lift but, amid the flurry of bad news beating on the market day-in day-out during that turbulent period, there were some reassuring moments. Consider the U.S. Treasury's announcement on the $19^{\text {th }}$ of September that it would provide a guarantee for money-market mutual funds. More to the point, closer examination of Figure 1 reveals that the price run-up experienced by the financials after the ban came into effect is about twice as large as the price run-up experienced by

\footnotetext{
${ }^{13}$ Exchange rates, as of 4:00 each day, were extracted from the Bank of Canada web site at: http://www.bankofcanada.ca/en/rates/exchange-look.html

${ }_{14}$ In Canada, lower margin requirements apply when the stock price exceeds $\$ 5$. Inferences from our regression analysis presented in Section 5 are unchanged when we expand our sample to include stocks meeting a minimum $\$ 1$ price threshold. During our sample period, 64 firms traded for less than $\$ 1$ and 109 firms traded for less than $\$ 5$ at some point.

${ }^{15}$ The OSC list of stocks facing the short sale prohibition comprises 12 interlisted firms, so 4 firms have been filtered out of our sample. Aberdeen Asia Pacific Income Investment Company Ltd. is excluded because it is not a common stock. Quest Capital Corp., Thomas Weisel Partners Group Inc, and Kingsway Financial are excluded because they fail to meet our minimum-price screen.
} 
the non-financial stocks. We hypothesize that the incremental price surge experienced by the financial stocks, relative to the non-financial stocks, captures the net effect of the short sale prohibition imposed on the financial stocks. In the analysis that follows, we will strive to tease out the specific impact of the short sale prohibition on the market by examining the dynamics of price differentials, market liquidity, and trading activity in the cross-listed pairs in the period surrounding the short sale prohibition.

We report descriptive statistics for our sample firms in Table 1 for the period starting on January 1, 2008 and ending on September 18th, 2008, the day before the short sale ban came into effect. This table provides an industry breakdown of our sample firms, based on Standard \& Poor's Global Industry Classification Standard (GICS). Our sample encompasses ten GICS industry sectors. The largest industry group represented in our sample is the materials sector, with 11 firms, followed by the energy sector, with ten firms. With eight firms, financial firms make up the third largest industry group, while the smallest group, utilities, is represented by one single firm. ${ }^{16}$ Across sectors, the average price differential for our sample pairs, which we calculate as the natural logarithm of the U.S. closing price minus the natural logarithm of the Canadian closing price converted into U.S. dollars $[\ln ($ U.S. price) $-\ln ($ Canadian price)], is less than 15 bps from parity, ranging between 15.4 bps for real estate sector to -7.3 bps for the information technology sector (column 4). On average, financial sector firms trade at a 5.5 bps discount in the U.S. relative to Canada. In column 5, the absolute value of the price differential ranges between 20 bps for the energy sector to over $50 \mathrm{bps}$ for the real estate sector. Across the ten industrial sectors represented in our sample, we observe an inverse relationship between the average absolute price differential and average firm size, which could be due to illiquidity, sparse trading, and a slower rate of incorporation of information into the prices of small stocks. ${ }^{17}$ Financials lie at the low end of the distribution in terms of absolute price differentials and relative bid-ask spreads and they lie at the high end of the distribution in terms of market capitalization and the share of total trading volume that is captured by the Canadian market. For most sectors, U.S. relative bid-ask spreads are lower on average than in Canada. This is true for the financials, with an average relative bid-ask spread of $14 \mathrm{bps}$ in the U.S. and 23 bps in Canada. Compared to most other sectors, a much larger proportion of overall trading volume for financials takes place in Canada. This is likely attributable to three important factors: 1) restrictions on ownership concentration in large banks, 2) bank governance rules requiring several board

\footnotetext{
${ }^{16}$ We re-classified five financial firms into the real estate sector since these firms were not subject to the shortselling ban and since their primary focus was real estate rather than banking. The five firms in question are: Brookfield Asset Management, Brookfield Properties, CP HOLDRS, FirstService Corporation, and MI Developments Inc.

${ }^{17}$ This finding is consistent with the inverse relationship between firm size and cross-listed stock price differentials documented by Gagnon and Karolyi (2009) in a broad-based study of cross-listings from 35 countries.
} 
functions and a substantial portion of directorships to be held in Canada, and 3) a historical limit of 25\% aggregate foreign ownership of banks. ${ }^{18}$

Figure 2 illustrates the behaviour of price differentials for the two groups of stocks, i.e. financials and non-financials, around the short sale ban. Prior to the ban, price differentials across the two groups are small and quite similar in magnitude. Prior to the ban also, the average price differentials fluctuate around a much narrower band than during and after the ban. The first break in this pattern occurs on September $18^{\text {th }}, 2008$, (i.e. on the day preceding the announcement of the short-selling ban) when the average price differential for non-financials reaches its peak value and when an equally intriguing surge in the bid-ask spreads of non-financials occurs in the Canadian market, suggesting a drop in the liquidity of non-financial stocks on that day. September 18, 2008, was an especially eventful day. On that day, the SEC announced a naked short selling ban on all stocks and the FSA announced its short-selling ban also.

In Table 2, we observe a marked increase in the magnitude of the price differentials of the financials as well as a surge in their standard deviation during the ban. The mean and median price differentials for the financials are $68 \mathrm{bps}$ and $41 \mathrm{bps}$, respectively, during the ban period. Mean (median) price differentials before and after the ban are very similar: -6 bps (-1 bps) before and -3 bps (-6 bps) after. We also observe a marked increase in the mean and median price differentials for the stocks included in the control group but the increase is much more modest for these stocks than for the financials. In the post-ban period, among the financials, the standard deviation of the price differentials as well as the absolute value of the price differentials remains high but they drop markedly. Contrastingly, for the control group, the standard deviation and the absolute value of price differentials both increase over time, and show no sign of reversal after the ban. These observations are borne out by Figures 2 and 3 .

Figure 4 shows the evolution of bid-ask spreads for the two groups of stocks, both in the U.S. and Canada, during our sample period. We observe a marked increase in the average bid-ask spread series of the two groups of stocks but the increase is much more sizable for the financial stocks, especially in the U.S. Similarly, in Figure 4, we report a higher increase in relative bid ask spreads for the non-financial stocks than for the financial stocks during the ban period in Canada while, in the U.S., we observe the exact opposite phenomenon. In the U.S., the average relative bid-ask spreads increased by over 70 bps for financials, about double the increase in relative bid-ask spreads for non-financials. In our empirical section we will use firm-level data to investigate the relation between all of these variables in greater detail.

\footnotetext{
${ }^{18} \mathrm{http} / /$ www.tc.gc.ca/pol/en/report/research/tp14500e/tp14500e.pdf Note that the telecommunications sector also has foreign ownership restrictions.
} 
The top chart in Figure 5 shows total normalized dollar volume of trading in both countries combined. In constructing these series, we normalize the trading volume of each stock based on the stock's mean and standard deviation of trading volume estimated over the period from January 1, 2008 to August 31, 2008. We note an increase in total dollar volume during the ban for both groups of stocks, with a larger increase in financial stocks. This increase is concentrated around the announcement of the short sale ban. On September 18, 2008, the day prior to the enactment of the short-selling ban, the average normalized trading volume of financial stocks peaked to a value of 8 in both the U.S. and Canada. Again, this could be due to the SEC's comprehensive ban on naked short-selling or to the FSA's short-selling ban announcement (or to another news item) but we have no way of pin-pointing the exact cause of this surge. Since these announcements were made at a different time on September 18, one would have to examine intra-day data in order to shed light on the source of this surge, if it is attributable to one single announcement. In the bottom chart of Figure 5, we show the median share of overall trading in each group of stocks that is captured by the Canadian market. In this chart, we see a distinct surge in the share of the financials' aggregate trading volume captured by the Canadian market which lasts up until the day when the short sale ban is cancelled. In Table 2, we report an increase in the average Canadian share of trading volume from just under $74 \%$ pre-ban to $82 \%$ during the ban, and then a fall back to $71 \%$ after the ban. We see no such pattern with the group of stocks not subjected to the short sale ban. Clearly, the short sale ban imposed on financial stocks caused a significant shift in trading activity of the financials back to the Toronto Stock Exchange (TSX). One plausible explanation for this phenomenon is that pessimistic investors captured a larger proportion of trading activity on the U.S. side before the ban and that they withdrew from the market during the ban. Another explanation may be that a greater share of the trading volume in the U.S. before the ban was attributable to arbitrageurs who had to put their activities on hold once the short sale ban came into effect. Plausible as these two explanations may be, the overall trading volume in the restricted stocks did not appear to be affected during the ban.

Figure 6 shows the proportion of shares outstanding that were shorted in each market and for each group of stocks (financials and non-financials) during our sample period. ${ }^{19}$ The proportion of shares sold short is much larger in the U.S. than in Canada, for both groups. This finding seems to contradict Ackert and Athanassakos (2005), who argue that informed traders short sell Canadian cross-listed stocks in Canada rather than in the U.S., in order to exploit the comparatively lower execution costs facing market participants in Canada. However, one must bear in mind that their investigation is based on a sample period that precedes the elimination of the price-test rule (the so-called up-tick rule) that was in place in

\footnotetext{
${ }^{19}$ The short interest data is based on reports of short interest in all customer accounts that broker / dealers must periodically submit to U.S. and Canadian stock exchanges.
} 
the U.S. at the time. ${ }^{20}$ Figure 6 reveals a distinct upward trend in short interest in Canadian bank stocks on the U.S. side in the period leading to the ban and an equally distinct downward trend in short interest in the same group of stocks on the Canadian side. Just prior to the short sale ban, the average relative short interest was almost twice as high in the U.S. as it was in Canada and, after the ban was imposed, short interest fell much more sharply in the U.S. than in Canada. A drop in the average relative short interest of non-financial stocks in the U.S. occurred at the same time. There is no clear explanation for this phenomenon although the SEC's crackdown on naked short selling around Lehman's bankruptcy and AIG's bailout may have something to do with this. Finally, that Canada accounts for roughly $80 \%$ of the aggregate trading volume in Canadian financials (Figure 5, bottom figure) and that short interest in this group of stocks was considerably higher in the U.S. that in Canada throughout our sample period (Figure 6) suggests that pessimists play a much greater role in the U.S. market than in Canada. We will elaborate on the implications of this and other findings discussed above in the next section.

\section{Empirical Findings}

\section{A. Regression Analysis}

In this section we implement fixed-effects panel regressions, described in Equation (1), in order to measure the effect of the short selling ban on several key variables of interest, including price differentials, the absolute value of these price differentials, bid-ask spreads and the share of trading volume on Canadian exchanges. We report firm cluster-robust standard errors throughout our regression tables in order to account for potential cross-sectional dependence of regression residuals across firms.

Table 3 examines the effect of the short-selling ban on the U.S.-Canada price differentials. In Model (1), we include an indicator variable (Short Ban) which is set to one during the period of the short sale ban, i.e. on each trading day between September $19^{\text {th }}$ and October $8^{\text {th }}, 2008$ inclusive, and zero on all other days. We also include an indicator variable (Post Short Ban) which is set to one on each day following the elimination of the ban, i.e. from October $9^{\text {th }}$ through November $30^{\text {th }}$ inclusive and zero on all other days. As well, we include two variables which capture the interaction between a financial sector

\footnotetext{
${ }^{20}$ When Ackert and Athanassakos (2005) conducted their study, it was comparatively easier to short sell a stock in Canada because execution costs were lower: short sales could be implemented on a zero tick; shares did not have to be borrowed before they were sold short; and margin requirements associated with short sales of optioned stocks were lower. Since then, on June 13, 2007, the SEC voted to adopt amendments to Rule 10a-1 (17 CFR 240.10a-1) and Regulation SHO (17 CFR 242.200 et. seq.), thereby removing Rule 10a-1 as well as any existing exchange mandated short-sale price-test. This new rule came into effect on July 6, 2007. Moreover, the SEC voted to prohibit any self-regulatory organization (SRO) from having a price test in the future. See Diether, Lee, and Werner (2007) and Alexander and Petersen (2008) for investigations of the impact of the temporary suspension of short-sale pricetests on a subset of NYSE and NASDAQ-listed stocks.
} 
indicator variable and each one of the two aforementioned ban and post-ban indicator variables. ${ }^{21}$ The interaction variable labeled Financial * Short Ban is the key variable in our experiment. Under the null hypothesis that the short sale ban has no effect, we expect the coefficient associated with this variable to be statistically indistinguishable from zero. In Model (1) of Table 3, the coefficient associated with this variable is equal to 60.600 and is statistically significant at the $1 \%$ level. This means that, during the short sale ban, financials stocks experienced an incremental increase of $61 \mathrm{bps}$ in their price differentials relative to non-financial firms. The coefficient associated with Short Ban indicates that non-financials experienced a surge in their price differentials as well, although to a much more modest extent (13 bps) and to a lesser degree of statistical significance (5\%) than financials. This result provides strong support for our conjecture that the short selling ban resulted in higher price differentials for financials because these stocks were more shorted more heavily in the U.S. prior to the ban. After the short sale ban period, the price differentials for non-financials were $15 \mathrm{bps}$ lower than before the ban, whereas financials experienced only a moderate 2 bps rise relative to the pre-ban period (combined effect of -15 bps +17 bps). Therefore, the impact on price differentials that manifested itself during the ban period dissipated in the post-ban period, supporting the notion that the change in the price differentials is mainly largely attributable to the ban rather than to some other factor.

In Model (2) of Table 3, we include Relative Bid-Ask Spread for the U.S. and the corresponding measure for Canada in order to control for the potential influence of liquidity shifts on the inferences that we drew from Model (1). In this new specification, we also include a high-frequency proxy for the volatility of each stock (Daily \% Trading Range). We calculate this volatility proxy by dividing the difference between a stock's daily high and closing prices by the mid-point between these two values and express this proxy in percentage terms (see Appendix A for variable descriptions). This volatility proxy has been used frequently in the empirical finance literature (e.g., Garman and Klass, 1980; Parkinson, 1980; Beckers, 1983; Rogers and Satchell, 1991; Anderson and Bollerslev, 1998). As it turns out, the coefficients associated with the U.S. and Canadian Relative Bid-Ask Spread variables as well as the volatility proxy are all statistically insignificant. The inclusion of these three control variables in Model (2) does not have a significant impact on the other coefficients in this regression. This result provides strong support for our hypothesis that the surge in the price differentials experienced by the short-selling restricted stocks is primarily driven by the short sale prohibition and that it is independent from changes in firm-specific as well as market-wide factors that may have been exerting an influence on the stocks

\footnotetext{
${ }^{21}$ We do not include a financial firm indicator variable in our regressions since it would be swept away by the firm fixed effects included in our regressions.
} 
during the ban. ${ }^{22}$ In Model (3) of Table 3, we remove Short Ban and Post Short Ban from the regression specification and include daily time fixed effects instead in order to control for market-wide factors that may not be captured by our other firm-level control variables. As Table 3 shows, the magnitude of the coefficient associated with Financial * Short Ban interaction as well as its statistical significance are insensitive to the inclusion of these fixed effects.

In Table 4, we control for the possibility that positive and negative market price movements in either market may exert an asymmetric impact on the price differentials. If we interpret days when the market goes up as days when the market is dominated by optimistic traders and days when the market goes down as days when the market is dominated by pessimists, we expect the effect of the short sale ban on price differentials to be more pronounced on days when the market is dominated by pessimistic investors than on days when the market is dominated by optimistic ones because, when short sales are prohibited, pessimistic investors simply cannot incorporate their pessimistic beliefs into stock prices by way of a short sale. Given the relatively higher degree of short selling activity taking place among financial stocks in the U.S., (e.g. Figure 6), we expect this asymmetric effect to be especially important in the U.S. The impact of the asymmetry is also likely to be exacerbated by the fact that trading in these stocks is much more liquid in Canada than in the U.S. and also by the fact that ownership in these stocks is much more widely distributed among Canadian investors than among U.S.-based investors. To the extent that dispersion of ownership is more pronounced in Canada than in the U.S., market participants in Canada can incorporate their pessimistic beliefs into the stock price more easily than their U.S. counterparts without having to conduct a short sale to do so (i.e., by conducting a sale of stock they already own). We include an indicator variable for the U.S. market (Negative SP500 Return), which we set equal to one on days when the index return is negative and zero otherwise, as well as one for the Canadian market (Negative SPTSX Return), which we construct in the same manner. We use Standard \& Poor's 500 Index to represent the U.S. market and the S\&P TSX Index to represent the Canadian market. We also include variables capturing the interaction between our market pessimism indicator variables with Financial and Short Ban indicator variables: Negative SP500 Return * Financial, Negative SP500 Return * Short Ban, Negative SP500 Return * Short Ban * Financial, for the U.S. and Negative SPTSX Return * Financial, Negative SPTSX Return * Short Ban, Negative SPTSX Return * Short Ban *

\footnotetext{
${ }^{22}$ It may be that the lack of statistical significance on the control variables is due to the implicit assumption that the control variables have the same impact on the two groups of stocks when in fact this may not be the case. In order to control for this possibility, we implemented a regression in which we interacted the Financial dummy variable with each of these control variables. We found that only one of these interaction terms, Financial* Daily \% Trading Range, was significant and that the coefficient on Financial * Short Ban was 60 bps, similar to the other models reported in Table 3. .
} 
Financial, for Canada. Model (1) includes our U.S. market pessimism variables, Model (2) includes our Canadian market pessimism variables, and Model (3) includes both sets of variables. ${ }^{23}$

In Model (1) of Table 4, we report that cross-listed price differentials are 3 bps lower on negative return days in the U.S. than on positive return days during the non-ban period. The price differential on positive market return days during the non-ban period, after controlling for other factors, is represented by the regression model's constant term and is equal to 0.99 bps. These two figures imply that U.S prices are approximately equal to Canadian prices on both positive and negative market return days. The coefficients associated with the interaction of this term with the Financial indicator variable is small and statistically insignificant, so we can conclude that both groups of firms behaved in the same way during the period leading to the ban and during the period following the ban. During the short-selling ban period, the non-financials' price differentials do not exhibit any behaviour different from the non-ban period. However, the coefficient associated with the interaction between Negative SP500 Return, Short Ban, and Financial is equal to 100.95 bps and is highly statistically significant. This shows that during the short sale ban period, the price differentials were, on average, $101 \mathrm{bps}$ higher for the cross-listed financials than for non-financials on negative return days and that they were equal to the non-financials on positive return days.

In Model (2), we include our Canadian pessimism indicator variables instead of their U.S. counterparts and observe patterns that are qualitatively similar to those revealed in Model (1). In model (3), which includes pessimism variables for both markets, the interaction coefficients on the variables including our Negative SP500 Return indicator variable remain similar in magnitude to the coefficients reported in Model (1) but the coefficients associated with Negative SPTSX Return are no-longer statistically significant as we expand Model (2) to include the U.S. pessimism variables. Overall, given that the financials' price differentials were statistically indistinguishable from the non-financials' on positive return days during the ban, our evidence shows that the effect of the short sale ban was concentrated on negative market return days. Our findings establish a strong link between the surge in the average U.S.-Canada price differentials experienced by the financial stocks during the ban and the withdrawal of proportionately more influential pessimist traders on the U.S. side during the ban.

Since the short selling ban may also have had an effect on arbitrage without necessarily having a large impact on the average of the price differentials, In Table 5, we focus on the absolute value of the natural logarithm of price differentials as a dependent variable (Abs Ln Price Differential). We interpret

\footnotetext{
${ }^{23}$ During the ban, 32 of our 112 firm-date financial company observations occur on positive SP500 market return days
} 
this direction-free measure of arbitrage differentials as a high-frequency proxy for the volatility of these price differentials. In the first column, we examine the effect of the short-selling ban without additional control variables. During the ban, the non-financials' absolute price differentials were 45 bps higher than in the non-ban period, which is highly statistically significant. At the same time, the financials' absolute price differentials were $52 \mathrm{bps}$ larger than for the control group, which represents a combined increase of over 90 bps relative to the non-ban period. Therefore, while the short-selling ban seems to have had an impact on stocks that were not subject to the ban, we observe the largest impact among the stocks that were subjected to the trading ban, regardless of direction. Moreover, Table 5 reveals a statistically significant increase in absolute price differentials for all stocks after the end of the short sale ban, relative to the pre-ban period. The interaction between the post-ban indicator variable and the Financial indicator variable is small and insignificant, so there was no difference in the behaviour in the absolute price differentials across the two groups of stocks in the period following the ban relative to the period preceding the ban.

Table 5 also reveals a smaller change in the non-financials' absolute price differentials once we control for Relative Bid-Ask Spreads in both markets as well as for Daily \% Trading Range, which suggests that the drop in liquidity and increase in volatility are responsible for a large part of the increase exhibited by the absolute price differentials of the non-financials during and after the ban. On the other hand, the coefficient associated with the Financial * Short Sale Ban Period interaction maintains its statistical significance as we move from Model (1) to Model (2) although it falls in magnitude from 52 bps from Model (1) to Model (2) and beyond. This finding suggests that the impact of the ban on the financials' price differentials documented in Table (3) and (4) is robust to the inclusion of liquidity and volatility control variables. The coefficients associated with all three of our control variables are statistically significant and they all have the expected sign. The coefficient estimate associated with Daily \% Trading Range, roughly 0.04 across the five models, implies a 40 bps increase in the absolute price differential of a given pair for a $10 \%$ increase in the value of Daily $\%$ Trading Range (i.e. from $1 \%$ to $11 \%$ ), a likely occurrence during and after the short sale ban. The coefficients associated with both Relative Bid-Ask Spreads variables are somewhat less significant from an economic standpoint, likely due to the high degree of correlation between these two variables.

In Models (3) and (4) of Table 5, we introduce two variables to control for the potential influence of changes in market-wide volatility on our inferences. In Model (3), we include the CME Group's volatility index (VIX Index) as a measure of market-wide volatility and, in Model (4), we use the one- 
month volatility of the exchange rate (USD/CAD Volatility Index) ${ }^{24}$ The coefficient associated with VIX Index in Model (3) is equal to 0.6 and is highly statistically significant. During our sample period, the VIX index ranged from 16 to 80, with a standard deviation of 16. Therefore, a one standard deviation change in the VIX index would be associated with an increase of $10 \mathrm{bps}$ in the absolute value of price differentials. In Model (4), the coefficient associated with USD/CAD Volatility Index is not statistically significant. The inclusion of the VIX variable also reduces the magnitude of our Short Sale Ban Period and of our Post Short Sale Ban Period indicator variables, suggesting that market-wide factors can explain a large portion of the movement in the non-financials' absolute price differentials during and after the ban.

Since the increase in the non-financials' absolute price differentials is more moderate after controlling for bid-ask spreads, we analyze the impact of the short sales ban on bid-ask spreads in Table 6. This exercise is also motivated by Diamond and Verrecchia (1987), who predict an increase in bid-ask spreads in the presence of short sales restrictions. We examine relative bid-ask spreads on the Canadian market in Panel A and on the U.S. market in Panel B. In Panel A, we observe a statistically significant 65 bps increase in the relative bid-ask spreads for both groups of stocks during the ban but no discernable incremental impact on the bid-ask spreads of the financials, judging by the small and statistically insignificant coefficient associated with the Financial * Short Ban indicator variable. The non-financial stocks' bid-ask spreads increase even further in the period following the ban, likely because the credit crisis went from bad to worse in the Fall of 2008, but the financials' bid-ask spreads reversed most of their gains after the ban, with a coefficient of -59 bps for the Financial * Post Short Ban interaction. This reversal in bid-ask spreads for the financials is robust to the inclusion of firm-specific and market-wide volatility, as proxied by Daily \% Trading Range and VIX Index, in Models (2) and (3) of Table 5 and it accords well with the Diamond and Verrecchia (1987) model. On the U.S. side, in Panel B, we report similar findings to Canada except that the financials experience a large and statistically significant increase in their bid-ask spreads during the ban, over and above the increase experienced by the nonfinancial stocks, with a highly statistically significant coefficient equal to $37.2 \mathrm{bps}$ on Financial * Short Ban in Model (1). This accords even better with the Diamond and Verrecchia (1987) model although the lack of reversal in the financials' bid-ask spreads after the ban is a challenge to this theory.

\footnotetext{
${ }^{24}$ The VIX index measures the near-term (30-day) expected volatility of the S\&P 500 Index and is inferred from the implied volatility of near-term and next-term call and put options on the SPX index. For a full explanation on the VIX construction methodology, see http://www.cboe.com/micro/vix/vixwhite.pdf. Since option prices may have been impacted by the short-selling ban, we also employ an alternative measure of market volatility, a rolling 20-day standard deviation of S\&P 500 returns, and obtain similar results with this alternative market volatility index.
} 
The bottom chart of Figure 5 showed a marked and sustained increase in the share of aggregate trading volume in financials captured by the Canadian market during the short sale ban and no similar effect among the non-financials. In Table 7, we perform a regression analysis similar to the one performed in Table 3, with the Canadian share of aggregate trading volume as the dependent variable (Canadian Share of Volume). Across the three regression models presented in this table, the coefficient associated with Financial * Short Ban indicates a 10\% increase, approximately, in Canada's share of aggregate trading volume in bank stocks during the ban. After the ban, between 3 and $4 \%$ of aggregate trading volume flows back to the U.S. In Model (2) and (3), the coefficient associated with Daily \% Trading Range is highly significant but small in economic magnitude. An increase in Daily \% Trading

Range from $1 \%$ to $11 \%$ implies a $0.03 \%$ decrease in the percentage of trading volume in Canada so we can be confident that volatility is a second order consideration in explaining the migration of trading volume between the two markets.

\section{B. Robustness Tests}

In an effort to curtail destabilizing short selling activity among bank stocks during the summer of 2008, the SEC launched a major crackdown on naked short selling of financial stocks. While this crackdown was not imposed on the financial stocks in our sample and was initiated long before the short selling of financial stocks was banned entirely, it may have had an effect on dynamics on the price differentials which is not properly accounted for in our tests. In separate regressions, we control for the possible influence of the naked short sale crackdown by including a crackdown indicator variable in our basis regression specification as well as an interaction between this indicator variable with the financial indicator variable. Since neither coefficient associated with these supplementary indicator variables is significant, we do not report these results in this paper.

Our results are also generally robust to transformations of our variables, such as taking logarithms of those variables that are bounded from below by zero (e.g. bid-ask spreads, absolute value of price differentials) and a logistic transformation of the Canadian share of trading, which lies in the $(0,1)$ range. In fact, our results are stronger, rejecting the hypothesis that $\beta_{2}=0$ for Canadian bid-ask spreads whereas previous results for this variable were statistically insignificant. Finally, we conducted tests to ascertain that our results are not driven by the behaviour of one or two firms in the sample. We replaced the shortsale interaction with interactions of the short period dummy with firm dummy variables for each of the eight financial firms in our sample, and find that all eight of these interaction terms are positive and statistically significant in the regression examining price differentials. 


\section{Concluding Remarks}

Although the tension between short sellers and market regulators is almost as old as organized exchanges, the impact of short selling restrictions on pricing efficiency is still not fully understood. ${ }^{25}$ In this paper, we examine this question from the unique vantage point of the selective short sale ban imposed in the U.S. and Canada in the early fall of 2008. We isolate the impact of OSC and SEC short sales restrictions on the trading attributes of a group of cross-listed Canadian stocks subjected to the short sale trading ban (i.e. the stocks of financial issuers) to the trading attributes of a control group of cross-listed Canadian stocks ( i.e. the non-financial stocks) which are not subjected to the short sale ban. This sampling strategy enables us to examine the impact of short sales restrictions in the two trading venues separately keeping the sample firms constant in each market and to gauge empirically, ceteris paribus, the sensitivity of arbitrage price differentials across markets to the presence of short sales restrictions. Overall, our findings reveal that the short sale ban of 2008 had a significant impact on the trading attributes of the stocks that were subjected to this ban, both in the U.S. and in Canada. During the ban, financials' trading volume migrated from the U.S. to the Canadian market, but returned back to the U.S. after the ban. Moreover, the U.S.-listings of these Canadian financial stocks were trading at a significant premium in relation to their Canadian listings during the short sale ban, but did not trade at a premium in the pre- or post- ban period, nor was there a substantial premium observed for non-financial stocks. Also, during the ban, this premium was only evident on negative U.S.-market return days. From an international version of Miller's (1977) investor optimism theory, these findings imply that pessimists were more preponderant in the U.S. during the short sale ban than in Canada and, from the perspective of a dualmarket version of the Bai, Chang, and Wang (2006) model, our findings imply that U.S. short sellers of Canadian cross-listed financial stocks were less informed than their home-market (Canadian) counterparts.

One drawback to our approach is that we do not have a randomly selected sample. The short sales restrictions were imposed on those firms (the financials) that were chosen by regulatory authorities and these firms are concentrated in the financial industry. The control sample firms belong to other industries, which may make it more difficult to compare behaviour between the two groups. Nonetheless, this is somewhat mitigated by our experimental design given that a large part of our focus is on the difference between the U.S. and Canadian prices of the same stock.

\footnotetext{
${ }^{25}$ According to Chancellor (2001), the first law prohibiting short selling was enacted by the Dutch government in 1610 in order to quash a "bear" raid that had been mounted secretly a year earlier against the East India Company by a group of Dutch businessmen. In the 1630s, England banned short selling after the tulip mania in the Netherlands to prevent similar fallout in England. More recently in Malaysia and Pakistan, short sellers have been faulted for stock market busts.
} 
Since short sales restrictions were imposed in many other countries and since the U.S. banned short-selling in foreign financial entities as well, future research could perform a similar analysis on cross-listed stocks from a broader sample of countries (e.g. the U.K.). This analysis might generate additional insights into the impact of short sales restrictions on asset prices but it would require the use of U.S. intraday data in order to circumvent problems associated with asynchronous trading hours in the U.S. and in most other markets. 


\section{References}

Abreu, D., and M. K. Brunnermeier, 2002, Synchronization risk and delayed arbitrage, Journal of Financial Economics 66, 341-360.

Abreu, D., and M. K. Brunnermeier, 2003, Bubbles and crashes, Econometrica 71, 173-204.

Ackert, L. F., and G. Athanassakos, 2005, The relationship between short interest and stock returns in the Canadian market, Journal of Banking \& Finance 29, 1729-1749.

Aitken, M. J., A. Frino, M. S. McCorry, and P. L. Swan, 1998, Short sales are almost instantaneously bad news: Evidence from the Australian stock exchange, The Journal of Finance 53, 2205-2223.

Alexander. G.J. and M. A. Peterson, 2008, The Effect of Price Tests on Trader Behavior and Market Quality: An Analysis of Reg. SHO, Journal of Financial Markets 11, 84-111.

Allen, Franklin, and Douglas Gale, 1991, Arbitrage, short sales, and financial innovation, Econometrica 59, 1041-1068.

Andersen, T.G., and T. Bollerslev, 1998, Answering the Skeptics: Yes, Standard Volatility Models Do Provide Accurate Forecasts, International Economic Review, 39, 885-905.

Bai, Y., and E. C. Chang, 2004, A model of stock price discovery under short sales constraints, Working Paper.

Bai, Y., E. C. Chang, and J. Wang, 2006, Asset Prices Under Short-Sale Constraints, Working Paper.

Beckers, S., 1983, Variance of Security Price Returns Based on High, Low, and Closing Prices, Journal of Business, 56, 97-112.

Brent, A., D. Morse, and E. K. Stice, 1990. Short interest: Explanations and tests. Journal of Financial and Quantitative Analysis 25 (2), 273-289.

Bris, A., W. N. Goetzmann, and N. Zhu, 2007, Efficiency and the bear: Short sales and markets around the world, Journal of Finance 62, 1029-1079.

Chancellor, E., (2001) "A short history of the bear", http://www.dailyreckoning.com/Issues/2001/110201.html.

Chang, E., and Y. Yu, 2004, Short-Sales Constraints and Price Discovery: Evidence from the Hong Kong Market, Working Paper, University of Hong Kong.

Charoenrook, A., and H. Daouk, 2005, A Study of Market-Wide Short-Selling Restrictions, http://ssrn.com/abstract $=687562$.

Danielsen, B. R. and S. M. Sorescu, 2001, Why Do Option Introductions Depress Stock Prices? A Study of Diminishing Short Sale Constraints, Journal of Financial and Quantitative Analysis 36, 451484.

D’Avolio, G., 2002, The Market for Borrowing Stock, Journal of Financial Economics 66, 271-306. 
Dechow, P., A. Hutton, Lisa Meulbroek, and Richard Sloan, 2001, Short-sellers, fundamental analysis, and stock returns, Journal of Financial Economics 61, 77-106.

Desai, H., Ramesh, K., Thiagarajan, S.R., Balachandran, B.V., 2002. An investigation of the informational role of short interest in the Nasdaq market, Journal of Finance 57 (5), 2263-2287.

Diamond, D. W., and R. E. Verrecchia, 1987, Constraints on Short-Selling and Asset Price Adjustment to Private Information, Journal of Financial Economics 18, 277-311.

Diether, K. B., K. H. Lee and I. M. Werner, 2007, It's SHO Time! Short-Sale Price-Tests and Market Quality, Working Paper.

Diether, K. B., C. J. Malloy, and A. Scherbina, 2002, Differences of opinion and the cross section of stock returns, Journal of Finance 57, 2113-2141.

Fama, E., 1970. Efficient capital markets: a review of theory and empirical work, Journal of Finance 25, 383-417.

Figlewski, S., 1981, The Informational Effects of Restrictions on Short Sales: Some Empirical Evidence, Journal of Financial and Quantitative Analysis 16, 463-476.

Figlewski, S., and G. Webb, 1993, Options, Short Sales, and Market Completeness, Journal of Finance 48, 761-777.

Gagnon, L., and G. A. Karolyi, 2009, Multi-market trading and arbitrage, Working Paper.

Garman, M.B., and M.J. Klass, 1980, On the Estimation of Price Volatility from Historical Data, Journal of Business, 53, 67-78.

Geczy, C. C, D. K. Musto, and A. V. Reed, 2002, Stocks are special too: An analysis of the equity lending market, Journal of Financial Economics 66, 241.

Harrison, J. M. and D. M. Kreps, 1978, Speculative Investor Behavior in a Stock Market with Heterogeneous Expectations, Quarterly Journal of Economics 92, 323-336.

Hong, H. and J. C. Stein, 2003, Difference of Opinion, Short-Sales Constraints and Market Crashes, Review of Financial Studies 16(2), 487-525.

Jones, C. M., 2003, Shorting restrictions, liquidity and returns, Working Paper, Graduate School of Busineses, Columbia University and the NYSE.

Jones, C. M., and O. A. Lamont, 2002, Short-sale constraints and stock returns, Journal of Financial Economics 66, 207-239.

Lamont, O. A., 2004, Go down fighting: short sellers versus firms, Working Paper, Yale School of Management.

Lamont, O. A., and R. H. Thaler, 2003, Can the market add and subtract? Mispricing in tech stock carveouts, Journal of Political Economy 21, 227-268.

Macey, J. R., M. Mitchell, and J. Netter, 1989, Restrictions on short sales: An analysis of the uptick rule and its role in view of the October 1987 stock market crash, Cornell Law Review 74, 799-835. 
Markowitz, H. M., 1953, Portfolio selection, Journal of Finance 7, 77-91.

Marsh, I. W. and N. Niemer, 2008, The impact of short sales restrictions, Commissioned by the International Securities Lending Association (ISLA), the Alternative Investment Management Association (AIMA), and the London Investment Banking Association (LIBA)

Miller, E. M., 1977, Risk, uncertainty, and divergence of opinion, Journal of Finance 32, 1151-1168.

Mitchell, M., T. Pulvino, and E. Stafford, 2002, Limited arbitrage in equity markets, Journal of Finance $57,551-584$.

Ofek, E. , and M. Richardson, 2003, DotCom mania: a survey of market efficiency in the internet sector, Journal of Finance 58, 1113-1138.

Parkinson, M., 1980, The Extreme Value Method for Estimating the Variance of the Rate of Return," Journal of Business 53, 61-65.

Rogers, L.C.G., and S.E. Satchell, 1991, Estimating Variance from High, Low and Closing Prices, Annals of Applied Probability 1, 504-512.

Ross, S., 1976. The arbitrage theory of capital asset pricing. Journal of Economic Theory 13, 341-360.

Scheinkman, J., and W. Xiong, 2003, Overconfidence and speculative bubbles, Journal of Political Economy 111, 1183-1219.

Shleifer, A., 1986. Do demand curves for stocks slope down? Journal of Finance 41, 579- 590.

Slater, J., 2008, Blame Game: Short selling not the reason for market woes, Canadian Investment Review 21, 49-50. 


\section{Appendix A: Variable Descriptions}

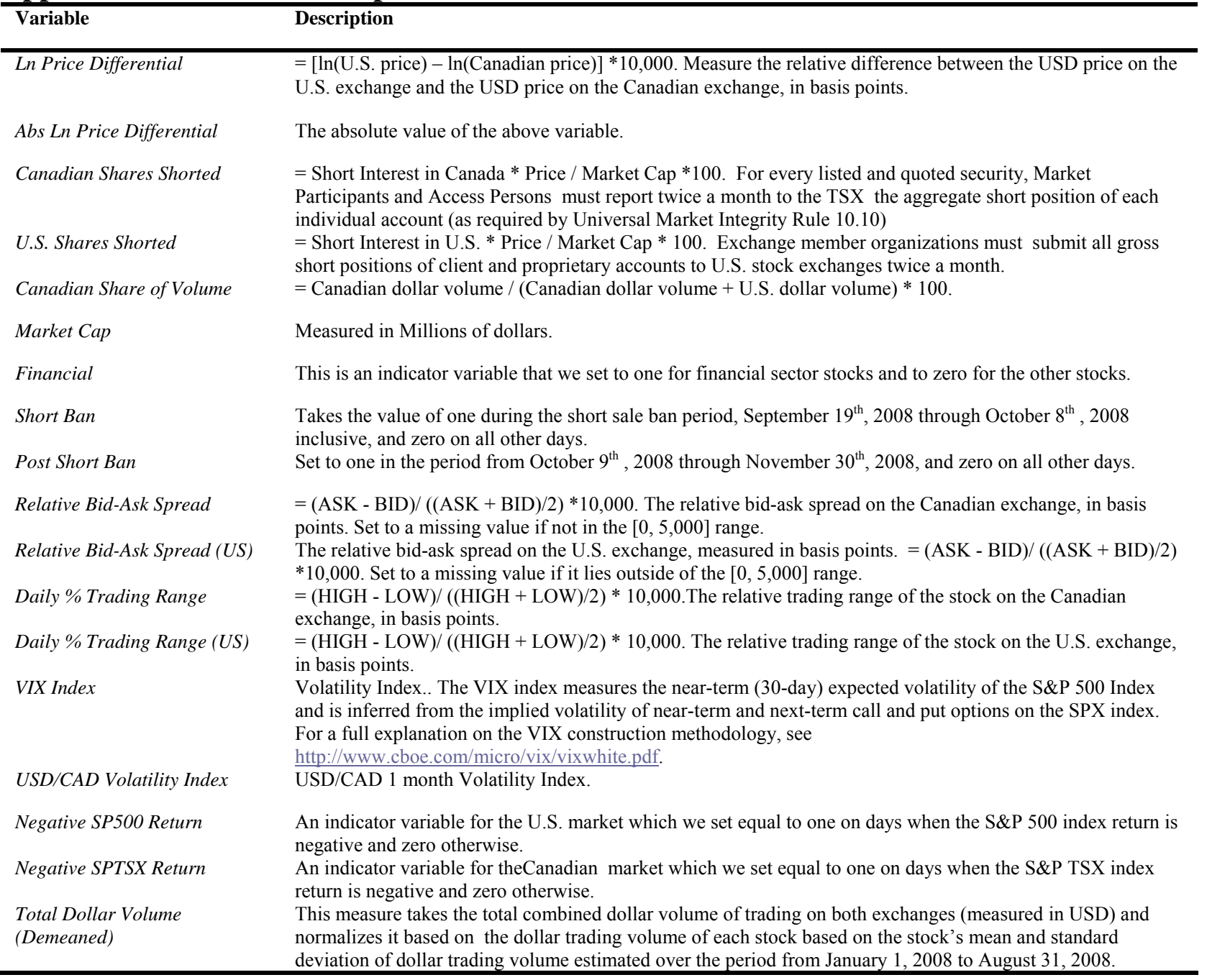


Table 1: Industry Characteristics. This table reports the number of daily observations as well as the mean of several key variables by GICS industry sector. The mean of each variable is measured from January 1, 2008 through September $18^{\text {th }}, 2008$. See the text or Appendix A for a description of the relevant variables. The eight financial sector firms included in the financials group below were all subjected to the short sale prohibition. This group consists of Bank of Montreal, Bank of Nova Scotia, Canadian Imperial Bank Of Commerce, Fairfax Financial Holdings Limited, Manulife Financial Corporation, Royal Bank of Canada, Sun Life Financial Inc., Toronto-Dominion Bank.

\begin{tabular}{|c|c|c|c|c|c|c|c|c|}
\hline Industry Sector & $\begin{array}{l}\text { Number } \\
\text { of firms }\end{array}$ & $\begin{array}{c}\text { Market } \\
\text { Cap (\$M) }\end{array}$ & $\begin{array}{c}\text { Ln Price } \\
\text { Differential }\end{array}$ & $\begin{array}{c}\text { Absolute } \\
\text { Value of } \\
\text { Ln Price } \\
\text { Differential }\end{array}$ & $\begin{array}{c}\text { Canadia } \\
\text { n Share } \\
\text { of } \\
\text { Volume }\end{array}$ & $\begin{array}{c}\text { Relative } \\
\text { Bid Ask } \\
\text { Spread } \\
\text { (Canada) }\end{array}$ & $\begin{array}{c}\text { Relative } \\
\text { Bid Ask } \\
\text { Spread } \\
\text { (U.S.) }\end{array}$ & $\begin{array}{l}\text { Number of } \\
\text { Observations }\end{array}$ \\
\hline Consumer Discretionary & 6 & 5,097 & 4.9 & 27.8 & 49.7 & 45.5 & 24.2 & 1,050 \\
\hline Energy & 10 & 31,332 & 2.5 & 19.9 & 55.5 & 17.4 & 9.8 & 1,750 \\
\hline Financials & 8 & 36,961 & -5.5 & 21.8 & 73.8 & 23.1 & 13.9 & 1,400 \\
\hline Health Care & 3 & 1,443 & -5.0 & 33.1 & 53.6 & 56.2 & 37.3 & 525 \\
\hline Industrials & 4 & 9,846 & -3.6 & 24.0 & 51.8 & 44.7 & 21.7 & 698 \\
\hline Information Technology & 4 & 17,975 & -7.3 & 33.9 & 38.2 & 50.1 & 17.0 & 700 \\
\hline Materials & 11 & 15,226 & 1.2 & 34.1 & 25.6 & 67.4 & 16.1 & 1,925 \\
\hline Real Estate & 5 & 6,117 & 15.4 & 51.5 & 42.4 & 117.0 & 62.3 & 807 \\
\hline Telecommunications & 3 & 23,111 & 4.2 & 24.9 & 83.2 & 25.6 & 13.7 & 525 \\
\hline Utilities & 1 & 6,824 & 1.9 & 14.8 & 91.6 & 16.5 & 21.8 & 175 \\
\hline Overall & 55 & 18,809 & 0.9 & 28.8 & 50.9 & 46.8 & 21.1 & 9,555 \\
\hline
\end{tabular}


Table 2: Summary Statistics Around the Short Sale Ban Period. This table reports summary statistics for both stocks affected by the short sale ban (financials) and those that were not during the pre- duringand post- period when these restrictions were in effect (Sept19th, 2008 to October 8th 2008). See the text for a description of the relevant variables.

\begin{tabular}{|c|c|c|c|c|c|c|}
\hline \multicolumn{7}{|c|}{ Ln Price Differential (Ln of U.S. price - Ln of Canadian Price) } \\
\hline & \multicolumn{3}{|c|}{ Non-Financials } & \multicolumn{3}{|c|}{ Financials } \\
\hline & Pre & During & Post & Pre & During & Post \\
\hline Mean & 2 & 16 & -12 & -6 & 68 & -3 \\
\hline Median & 0 & 4 & -11 & -1 & 41 & -6 \\
\hline Standard deviation & 55 & 129 & 138 & 39 & 166 & 105 \\
\hline \multicolumn{7}{|c|}{ Absolute Value of Ln Price Differential } \\
\hline & \multicolumn{3}{|c|}{ Non-Financials } & \multicolumn{3}{|c|}{ Financials } \\
\hline & Pre & During & Post & Pre & During & Post \\
\hline Mean & 30 & 76 & 89 & 22 & 119 & 68 \\
\hline Median & 18 & 39 & 57 & 14 & 72 & 40 \\
\hline Standard deviation & 46 & 105 & 106 & 33 & 133 & 80 \\
\hline
\end{tabular}

Relative Bid-Ask Spread on Canadian Exchange

\begin{tabular}{|c|c|c|c|c|c|c|}
\hline & \multicolumn{3}{|c|}{ Non-Financials } & \multicolumn{3}{|c|}{ Financials } \\
\hline & Pre & During & Post & Pre & During & Post \\
\hline Mean & 51 & 120 & 150 & 23 & 83 & 59 \\
\hline Median & 26 & 50 & 80 & 12 & 33 & 40 \\
\hline Standard deviation & 91 & 207 & 245 & 53 & 142 & 59 \\
\hline
\end{tabular}

Relative Bid-Ask Spread on U.S. Exchange

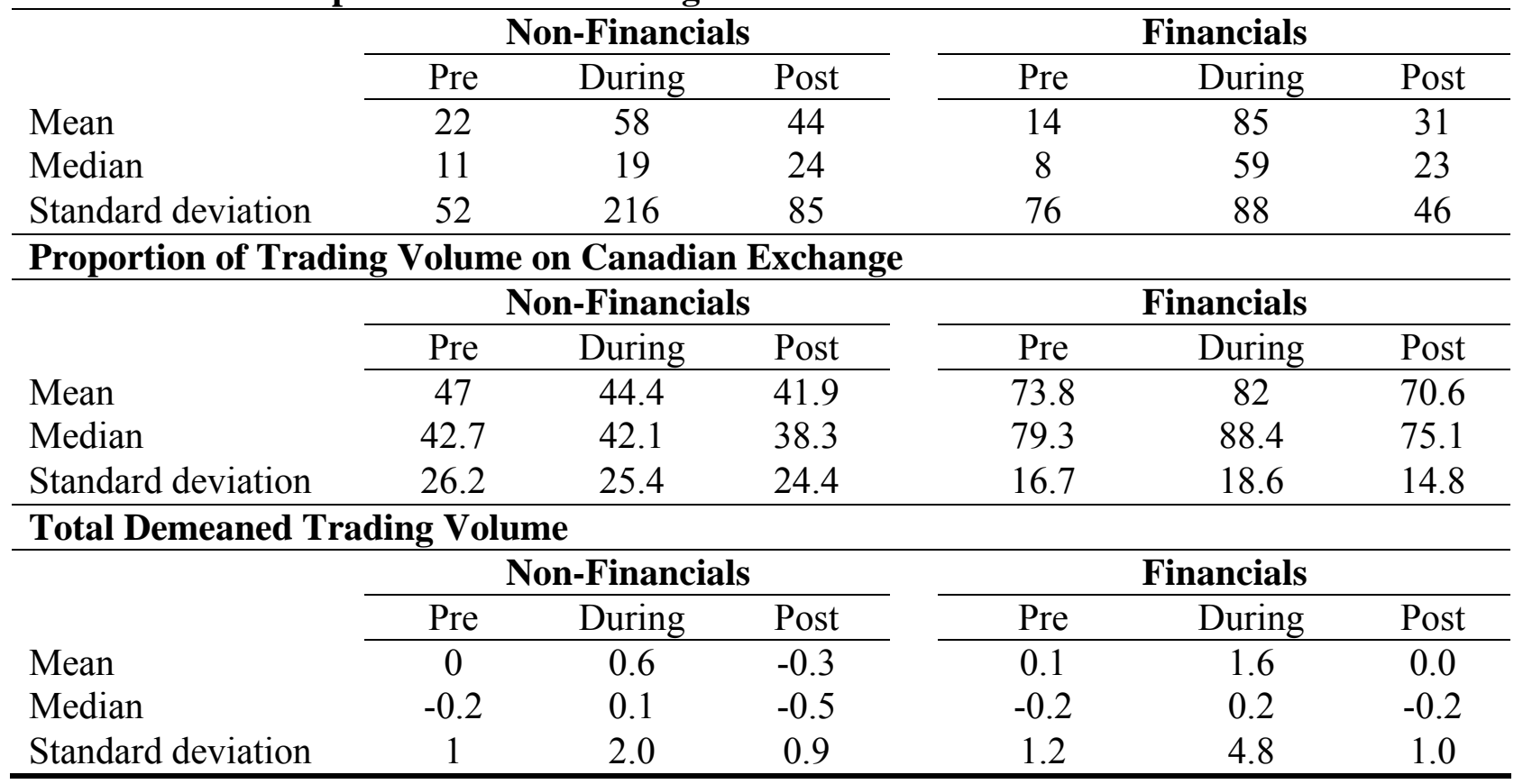


Table 3: Ln Price Differentials Fixed Effect Regressions. This table reports the results of fixed effects regressions for 55 sample firms, where the dependent variable is the natural logarithm price differential between each firm's U.S.-traded and Canadian-traded shares:

$$
p_{-} \text {diff }_{\text {it }}=\alpha+\beta_{1} D_{\text {BAN }, t}+\beta_{2} D_{\text {BAN }, t} \times D_{\text {FINANCIAL }, i}+\beta_{3} D_{\text {POST }-B A N, t}+\beta_{4} D_{\text {POST }-B A N, t} \times D_{\text {FINANCIAL }, i}+\sum_{\text {Controls }} \beta_{\text {Control }} \text { Control }_{i t}+\mu_{i}+e_{t}
$$

Descriptions of all variables are in Appendix A. Robust $\mathrm{t}$ statistics, adjusted for clustering at the firm level, are presented in parentheses. * significant at $10 \% ; * *$ significant at $5 \%$; ** significant at $1 \%$.

\begin{tabular}{lccc}
\hline & $\mathbf{( 1 )}$ & $\mathbf{( 2 )}$ & $\mathbf{( 3 )}$ \\
\hline Short Ban & 13.076 & 11.574 & \\
Financial * Short Ban & $(2.49)^{* *}$ & $(2.10)^{* *}$ & \\
& 60.600 & 68.888 & 70.968 \\
Post Short Ban & $(6.86)^{* * *}$ & $(5.33)^{* * *}$ & $(5.25)^{* * *}$ \\
& -14.742 & -16.679 & \\
Financial * Post Short Ban & $(3.46)^{* * *}$ & $(3.05)^{* * *}$ & \\
& 17.338 & 13.740 & 13.931 \\
Relative Bid-Ask Spread & $(1.95)^{*}$ & $(1.61)$ & $(1.69)^{*}$ \\
& & 0.004 & 0.001 \\
Relative Bid-Ask Spread (US) & & $(0.22)$ & $(0.04)$ \\
& & 0.031 & 0.015 \\
Daily \% Trading Range & & $(1.35)$ & $(0.70)$ \\
& & 0.001 & -0.002 \\
Constant & 1.101 & $(0.24)$ & $(0.28)$ \\
Observations & $(1.72)^{*}$ & $(0.351$ & 77.958 \\
Time Fixed Effects & 12090 & 11762 & $(1.62)$ \\
R-squared (within) & $\mathrm{NO}$ & $\mathrm{NO}$ & 11762 \\
\hline
\end{tabular}


Table 4: Market Returns and Ln Price Differentials - Fixed Effect Regressions. This table reports the results of fixed effects regressions for 55 sample firms, where the dependent variable is the natural logarithm price differential between each firm's U.S.-traded and Canadian-traded shares and includes interactions of our dummy variables with dummy variables indicating negative market index returns:

$$
p_{-} \text {diff }_{\text {it }}=\alpha+\beta_{1} D_{\text {BAN }, t}+\beta_{2} D_{\text {BAN }, t} \times D_{\text {FINANCIAL }, i}+\beta_{3} D_{\text {POST }-B A N, t}+\beta_{4} D_{\text {POST }-B A N, t} \times D_{\text {FINANCIAL }, i}+\sum_{\text {Controls }} \beta_{\text {Control }} \text { Control }_{i t}+\mu_{i}+e_{t}
$$

Descriptions of all variables are in Appendix A. Robust $\mathrm{t}$ statistics, adjusted for clustering at the firm level, are presented in parentheses. * significant at $10 \% ; * *$ significant at $5 \% ; * * *$ significant at $1 \%$.

\begin{tabular}{|c|c|c|c|}
\hline & (1) & (2) & (3) \\
\hline Short Ban & $\begin{array}{c}27.736 \\
(2.21)^{* *}\end{array}$ & $\begin{array}{l}22.902 \\
(1.85)^{*}\end{array}$ & $\begin{array}{c}28.331 \\
(2.02)^{* *}\end{array}$ \\
\hline Financial * Short Ban & $\begin{array}{l}-5.413 \\
(0.32)\end{array}$ & $\begin{array}{c}21.501 \\
(1.12)\end{array}$ & $\begin{array}{l}-6.853 \\
(0.34)\end{array}$ \\
\hline Post Short Ban & $\begin{array}{c}-16.505 \\
(2.98)^{* * *}\end{array}$ & $\begin{array}{c}-16.656 \\
(3.04) * * *\end{array}$ & $\begin{array}{c}-16.265 \\
(2.94) * * *\end{array}$ \\
\hline Financial * Post Short Ban & $\begin{array}{l}13.705 \\
(1.63)\end{array}$ & $\begin{array}{l}13.787 \\
(1.61)\end{array}$ & $\begin{array}{l}13.619 \\
(1.63)\end{array}$ \\
\hline Relative Bid-Ask Spread & $\begin{array}{l}0.003 \\
(0.16)\end{array}$ & $\begin{array}{l}0.003 \\
(0.19)\end{array}$ & $\begin{array}{l}0.003 \\
(0.16)\end{array}$ \\
\hline Relative Bid-Ask Spread (US) & $\begin{array}{l}0.031 \\
(1.32)\end{array}$ & $\begin{array}{l}0.031 \\
(1.33)\end{array}$ & $\begin{array}{l}0.031 \\
(1.32)\end{array}$ \\
\hline Daily \% Trading Range & $\begin{array}{l}0.002 \\
(0.34)\end{array}$ & $\begin{array}{l}0.001 \\
(0.21)\end{array}$ & $\begin{array}{l}0.002 \\
(0.30)\end{array}$ \\
\hline Negative SP500 Return & $\begin{array}{c}-3.373 \\
(2.38)^{* *}\end{array}$ & & $\begin{array}{c}-5.661 \\
(4.09)^{* * *}\end{array}$ \\
\hline Negative SP500 Return * Financial & $\begin{array}{l}0.208 \\
(0.09)\end{array}$ & & $\begin{array}{l}1.673 \\
(0.66)\end{array}$ \\
\hline Negative SP500 Return * Short Ban & $\begin{array}{c}-21.689 \\
(1.47)\end{array}$ & & $\begin{array}{c}-22.617 \\
(1.58)\end{array}$ \\
\hline Negative SP500 Return * Short Ban * Financial & $\begin{array}{c}100.950 \\
(3.53)^{* * *}\end{array}$ & & $\begin{array}{c}99.541 \\
(3.13)^{* * *}\end{array}$ \\
\hline Negative SPTSX Return & & $\begin{array}{c}3.889 \\
(2.08) * *\end{array}$ & $\begin{array}{c}6.013 \\
(3.16)^{* * *}\end{array}$ \\
\hline Negative SPTSX Return * Financial & & $\begin{array}{l}-3.176 \\
(1.07)\end{array}$ & $\begin{array}{l}-3.826 \\
(1.16)\end{array}$ \\
\hline Negative SPTSX Return * Short Ban & & $\begin{array}{c}-16.979 \\
(1.26)\end{array}$ & $\begin{array}{l}-0.904 \\
(0.07)\end{array}$ \\
\hline Negative SPTSX Return * Short Ban * Financial & & $\begin{array}{c}65.396 \\
(2.74) * * *\end{array}$ & $\begin{array}{l}4.059 \\
(0.16)\end{array}$ \\
\hline Constant & $\begin{array}{l}0.989 \\
(0.37)\end{array}$ & $\begin{array}{l}-1.901 \\
(0.69)\end{array}$ & $\begin{array}{l}-0.567 \\
(0.21)\end{array}$ \\
\hline Observations & 11762 & 11762 & 11762 \\
\hline $\begin{array}{l}\text { Time Fixed Effects } \\
R \text {-sauared (within) }\end{array}$ & $\begin{array}{l}\mathrm{NO} \\
002\end{array}$ & $\mathrm{NO}$ & NO \\
\hline
\end{tabular}


Table 5: Absolute Ln Price Differentials Fixed Effect Regressions. This table reports the results of fixed effects regressions for 55 sample firms, where the dependent variable is the absolute value of the $\ln$ price differential between each firm's U.S.traded and Canadian-traded shares:

$$
a b s\left(p_{-} \text {diff }\right)_{i t}=\alpha+\beta_{1} D_{\text {BAN }, t}+\beta_{2} D_{\text {BAN }, t} \times D_{\text {FINANCIAL }, i}+\beta_{3} D_{\text {POST-BAN }, t}+\beta_{4} D_{\text {POST }-B A N, t} \times D_{\text {FINANCIA }, i}+\sum_{\text {Controls }} \beta_{\text {Control }} \text { Control }_{i t}+\mu_{i}+e_{t}
$$

Descriptions of all variables are in Appendix A. Robust t statistics, adjusted for clustering at the firm level, are presented in parentheses. * significant at $10 \% ; *$ significant at $5 \% ; * *$ significant at $1 \%$.

\begin{tabular}{|c|c|c|c|c|c|}
\hline & (1) & (2) & (3) & (4) & (5) \\
\hline Short Ban & $\begin{array}{c}45.119 \\
(9.11)^{* * *}\end{array}$ & $\begin{array}{c}17.965 \\
(4.39)^{* * *}\end{array}$ & $\begin{array}{c}8.406 \\
(1.69)^{*}\end{array}$ & $\begin{array}{c}18.088 \\
(4.07)^{* * *}\end{array}$ & \\
\hline Financial * Short Ban & $\begin{array}{c}52.241 \\
(3.73)^{* * *}\end{array}$ & $\begin{array}{c}47.880 \\
(7.21)^{* * *}\end{array}$ & $\begin{array}{c}47.602 \\
(7.12)^{* * *}\end{array}$ & $\begin{array}{c}47.917 \\
(7.21)^{* * *}\end{array}$ & $\begin{array}{c}49.589 \\
(6.74)^{* * *}\end{array}$ \\
\hline Post Short Ban & $\begin{array}{c}57.485 \\
(13.05)^{* * *}\end{array}$ & $\begin{array}{c}16.458 \\
(5.25)^{* * *}\end{array}$ & $\begin{array}{l}-6.238 \\
(1.05)\end{array}$ & $\begin{array}{c}17.077 \\
(2.89)^{* * *}\end{array}$ & \\
\hline Financial * Post Short Ban & $\begin{array}{c}-10.883 \\
(1.51)\end{array}$ & $\begin{array}{l}-0.562 \\
(0.10)\end{array}$ & $\begin{array}{l}-0.851 \\
(0.15)\end{array}$ & $\begin{array}{l}-0.538 \\
(0.10)\end{array}$ & $\begin{array}{l}-1.216 \\
(0.23)\end{array}$ \\
\hline Relative Bid-Ask Spread & & $\begin{array}{c}0.158 \\
(2.97)^{* * *}\end{array}$ & $\begin{array}{c}0.157 \\
(2.97)^{* * *}\end{array}$ & $\begin{array}{c}0.158 \\
(2.97)^{* * *}\end{array}$ & $\begin{array}{c}0.145 \\
(2.91)^{* * *}\end{array}$ \\
\hline Relative Bid-Ask Spread (USmkt) & & $\begin{array}{c}0.047 \\
(2.13)^{* *}\end{array}$ & $\begin{array}{c}0.045 \\
(2.11)^{* *}\end{array}$ & $\begin{array}{c}0.047 \\
(2.13)^{* *}\end{array}$ & $\begin{array}{c}0.033 \\
(1.79)^{*}\end{array}$ \\
\hline Daily \% Trading Range & & $\begin{array}{c}0.043 \\
(9.94)^{* * *}\end{array}$ & $\begin{array}{c}0.040 \\
(8.66)^{* * *}\end{array}$ & $\begin{array}{c}0.043 \\
(9.98)^{* * *}\end{array}$ & $\begin{array}{c}0.035 \\
(7.44)^{* * *}\end{array}$ \\
\hline VIX Index & & & $\begin{array}{c}0.596 \\
(3.56)^{* * *}\end{array}$ & & \\
\hline USD/CAD Volatility Index & & & & $\begin{array}{l}-0.051 \\
(0.13)\end{array}$ & \\
\hline Constant & $\begin{array}{c}28.989 \\
(40.12)^{* * *}\end{array}$ & $\begin{array}{c}4.616 \\
(1.72)^{*}\end{array}$ & $\begin{array}{c}-8.034 \\
(2.07)^{* *}\end{array}$ & $\begin{array}{l}5.155 \\
(0.98)\end{array}$ & $\begin{array}{c}134.136 \\
(3.91)^{* * *}\end{array}$ \\
\hline Observations & 12090 & 11762 & 11762 & 11709 & 11762 \\
\hline Time Fixed Effects & NO & NO & NO & NO & YES \\
\hline R-squared (within) & 0.13 & 0.26 & 0.26 & 0.26 & 0.31 \\
\hline
\end{tabular}


Table 6: Bid Ask Spreads Fixed Effect Regressions. This table reports the results of fixed effects regressions for 55 sample firms, where the dependent variable is the firm's bid ask spread on Canadian (Panel A) and U.S. (Panel B) exchanges:

bid_ask $k_{i t}=\alpha+\beta_{1} D_{\text {BAN }, t}+\beta_{2} D_{\text {BAN }, t} \times D_{\text {FINANCIAL }, i}+\beta_{3} D_{\text {POST }-B A N, t}+\beta_{4} D_{\text {POST }-B A N, t} \times D_{\text {FINANCIAL }, i}+\sum_{\text {Controls }} \beta_{\text {Control }}$ Control $_{i t}+\mu_{i}+e_{t}$ Descriptions of all variables are in Appendix A. Robust t statistics, adjusted for clustering at the firm level, are presented in parentheses. ${ }^{*}$ significant at $10 \% ; * *$ significant at $5 \% ; * * *$ significant at $1 \%$.

\begin{tabular}{|c|c|c|c|}
\hline \multicolumn{4}{|c|}{ Panel A: Canadian Relative Bid-Ask Spread } \\
\hline & (1) & (2) & (3) \\
\hline Short Ban & $\begin{array}{c}65.420 \\
(5.71)^{* * *}\end{array}$ & $\begin{array}{c}34.961 \\
(3.00) * * *\end{array}$ & \\
\hline Financial * Short Ban & $\begin{array}{l}-5.350 \\
(0.22)\end{array}$ & $\begin{array}{r}-3.820 \\
(0.17)\end{array}$ & $\begin{array}{l}-3.992 \\
(0.17)\end{array}$ \\
\hline Post Short Ban & $\begin{array}{c}94.976 \\
(5.42)^{* * *}\end{array}$ & $\begin{array}{c}42.423 \\
(2.08) * *\end{array}$ & \\
\hline Financial * Post Short Ban & $\begin{array}{c}-59.091 \\
(3.32)^{* * *}\end{array}$ & $\begin{array}{c}-54.953 \\
(3.09) * * *\end{array}$ & $\begin{array}{c}-55.970 \\
(3.07) * * *\end{array}$ \\
\hline Daily \% Trading Range & & $\begin{array}{c}0.050 \\
(5.96) * * *\end{array}$ & $\begin{array}{c}0.038 \\
(4.10)^{* * *}\end{array}$ \\
\hline VIX Index & & $\begin{array}{c}0.678 \\
(2.96)^{* * *}\end{array}$ & \\
\hline Constant & $\begin{array}{c}47.479 \\
(17.77)^{* * *}\end{array}$ & $\begin{array}{c}13.747 \\
(2.67)^{* *}\end{array}$ & $\begin{array}{c}203.926 \\
(4.28)^{* * *}\end{array}$ \\
\hline $\begin{array}{l}\text { Observations } \\
\text { Time Fixed Effects } \\
R \text {-sawared (within) }\end{array}$ & $\begin{array}{l}11992 \\
\text { NO } \\
010 \\
\end{array}$ & $\begin{array}{c}11992 \\
\text { NO } \\
012 \\
\end{array}$ & $\begin{array}{l}11992 \\
\text { YES } \\
015 \\
\end{array}$ \\
\hline \multicolumn{4}{|c|}{ Panel B: U.S. Relative Bid-Ask Spread } \\
\hline & (1) & $(2)$ & (3) \\
\hline Short Ban & $\begin{array}{c}34.286 \\
(3.57)^{* * *}\end{array}$ & $\begin{array}{c}18.826 \\
(2.26)^{* *}\end{array}$ & \\
\hline Financial $*$ Short Ban & $\begin{array}{c}37.203 \\
(2.78)^{* * *}\end{array}$ & $\begin{array}{c}36.978 \\
(2.78)^{* * *}\end{array}$ & $\begin{array}{c}36.509 \\
(2.65)^{* *}\end{array}$ \\
\hline Post Short Ban & $\begin{array}{c}20.230 \\
(4.87)^{* * *}\end{array}$ & $\begin{array}{l}-11.439 \\
(2.47)^{* *}\end{array}$ & \\
\hline Financial * Post Short Ban & $\begin{array}{l}-3.301 \\
(0.51)\end{array}$ & $\begin{array}{l}-2.743 \\
(0.44)\end{array}$ & $\begin{array}{l}-2.953 \\
(0.46)\end{array}$ \\
\hline Daily \% Trading Range (US) & & $\begin{array}{c}0.011 \\
(2.27)^{* *}\end{array}$ & $\begin{array}{l}0.002 \\
(0.35)\end{array}$ \\
\hline VIX Index & & $\begin{array}{c}0.623 \\
(4.38) * * *\end{array}$ & \\
\hline Constant & $\begin{array}{c}21.417 \\
(25.18)^{* * *}\end{array}$ & $\begin{array}{l}2.882 \\
(0.78)\end{array}$ & $\begin{array}{c}102.635 \\
(3.95)^{* * *}\end{array}$ \\
\hline Observations & 11852 & 11852 & 11852 \\
\hline Time Fixed Effects & NO & NO & YES \\
\hline R-squared (within) & 0.03 & 0.04 & 0.08 \\
\hline
\end{tabular}


Table 7: Canadian Share of Aggregate Trading Volume Fixed Effect Regressions. This table reports the results of fixed effects regressions for 55 sample firms, where the dependent variable is the share of a firm's trading volume on Canadian exchanges:

$$
\text { canadian_share }_{i t}=\alpha+\beta_{1} D_{\text {BAN }, t}+\beta_{2} D_{\text {BAN }, t} \times D_{\text {FINANCIAL }, i}+\beta_{3} D_{\text {POST }-B A N, t}+\beta_{4} D_{\text {POST -BAN }, t} \times D_{\text {FINANCIAL }, i}+\sum_{\text {Controls }} \beta_{\text {Control }} \text { Control }_{i t}+\mu_{i}+e_{t}
$$

Descriptions of all variables are in Appendix A. Robust $\mathrm{t}$ statistics, adjusted for clustering at the firm level, are presented in parentheses. $*$ significant at $10 \% ; * *$ significant at $5 \% ; * * *$ significant at $1 \%$.

\begin{tabular}{lccc}
\hline & $\mathbf{( 1 )}$ & $\mathbf{( 2 )}$ & $(3)$ \\
\hline Short Ban & -1.673 & -0.570 & \\
Financial * Short Ban & $(2.16)^{* *}$ & $(0.67)$ & \\
& 9.955 & 9.889 & 10.037 \\
Post Short Ban & $(4.72)^{* * *}$ & $(4.71)^{* * *}$ & $(4.84)^{* * *}$ \\
& -4.248 & -2.599 & \\
Financial * Post Short Ban & $(4.46)^{* * *}$ & $(2.54)^{* *}$ & \\
& 1.061 & 0.793 & 0.913 \\
Relative Bid-Ask Spread & $(0.56)$ & $(0.42)$ & $(0.48)$ \\
& & -0.001 & -0.001 \\
Relative Bid-Ask Spread (US) & & $(0.66)$ & $(0.76)$ \\
& & 0.002 & \\
Daily \% Trading Range & & $(0.77)$ & \\
& & -0.003 & -0.002 \\
Constant & 50.788 & $(5.33)^{* * *}$ & $(2.78)^{* * *}$ \\
& $(325.08)^{* * *}$ & $(186.97)^{* * *}$ & $(24.46)^{* * *}$ \\
Observations & 12090 & 11762 & 11762 \\
Time Fixed Effects & $\mathrm{NO}$ & $\mathrm{NO}$ & YES \\
R-squared (within) & 0.04 & 0.04 & 0.12 \\
\hline
\end{tabular}


Figure 1: Price of Financial and Non-Financial Crosslisted Stocks

\section{Price of Crosslisted Stocks}
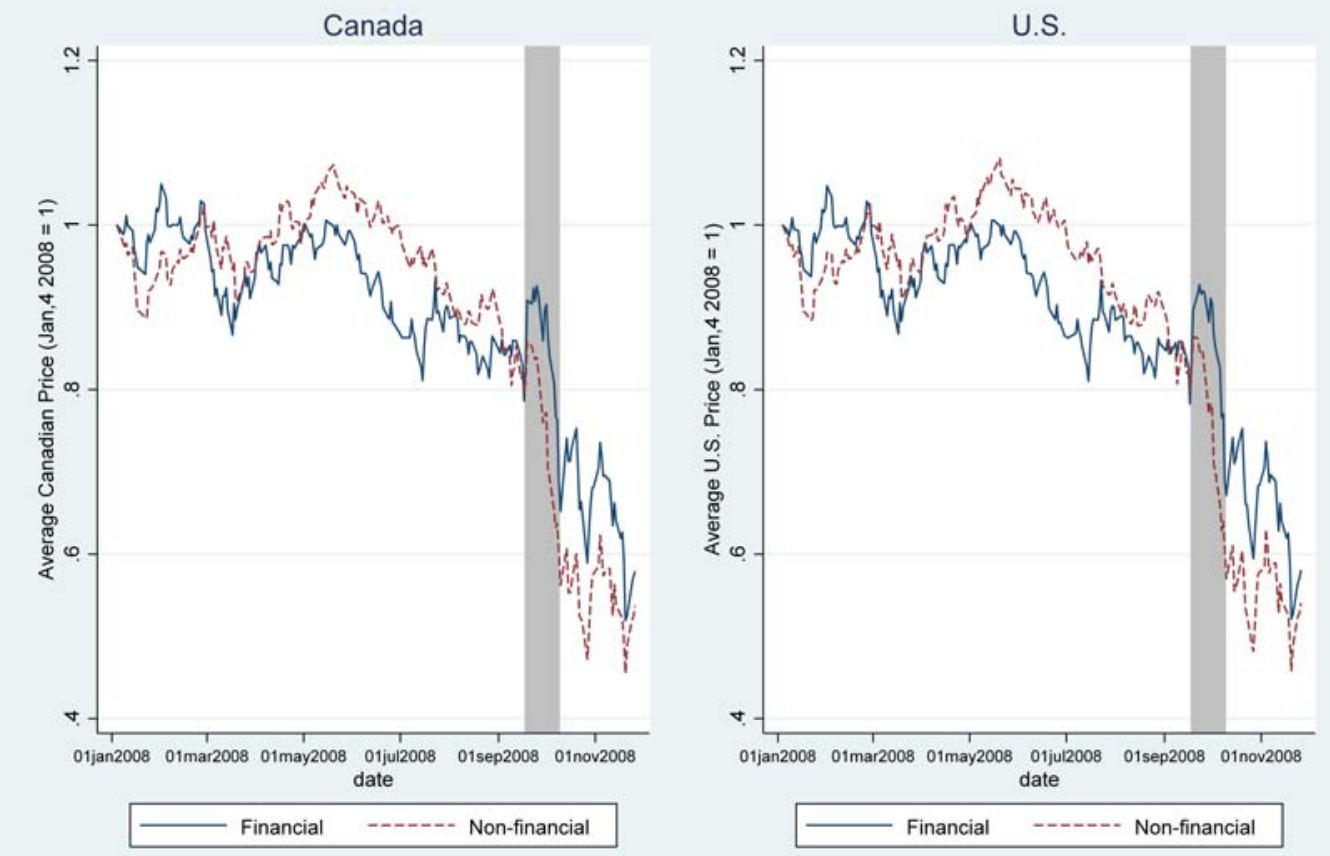
Figure 2: Ln Price Differentials for Financial and Non-Financial Stocks

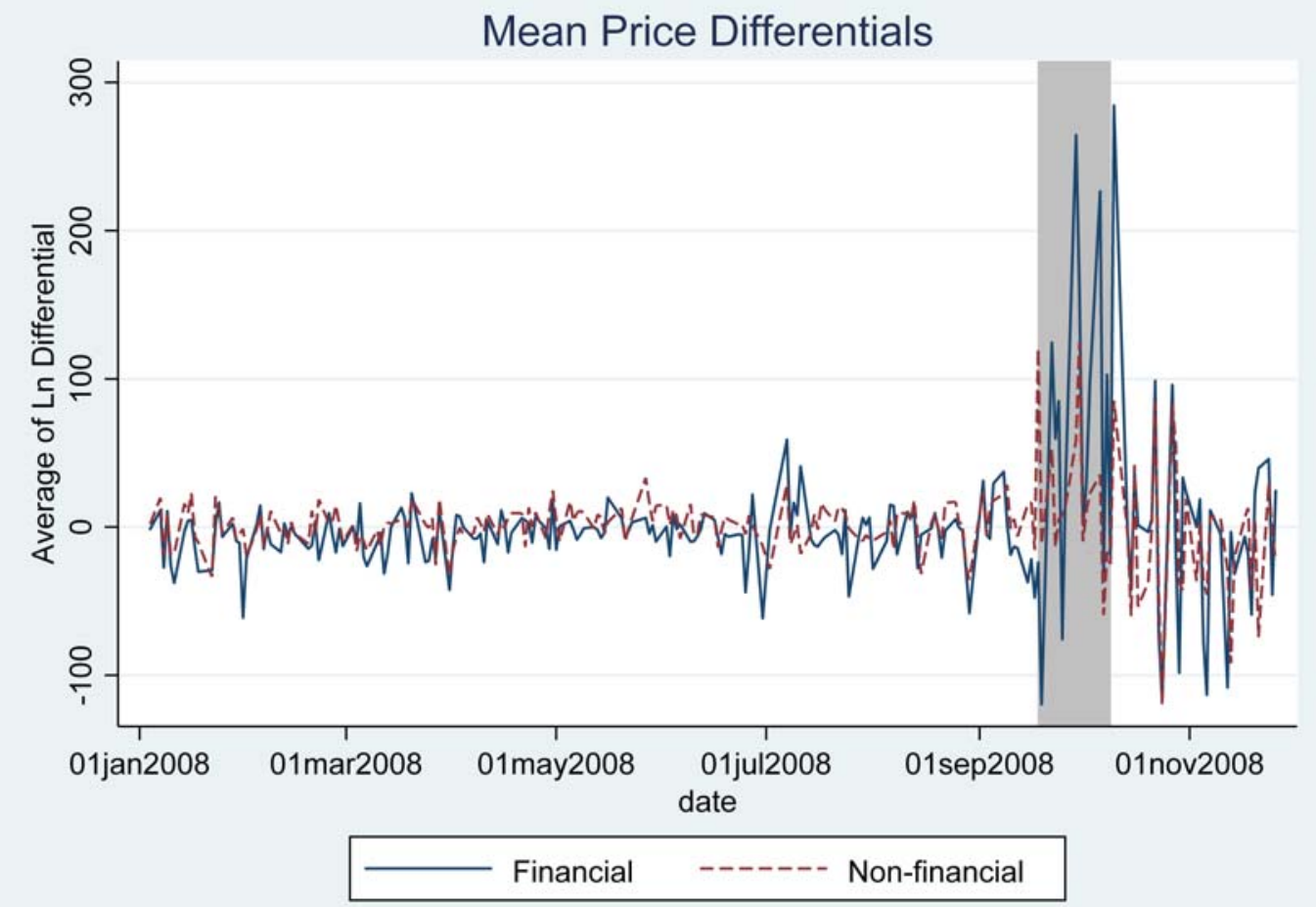


Figure 3: Absolute Value of Ln Price Differentials for Financial and Non-Financial Stocks

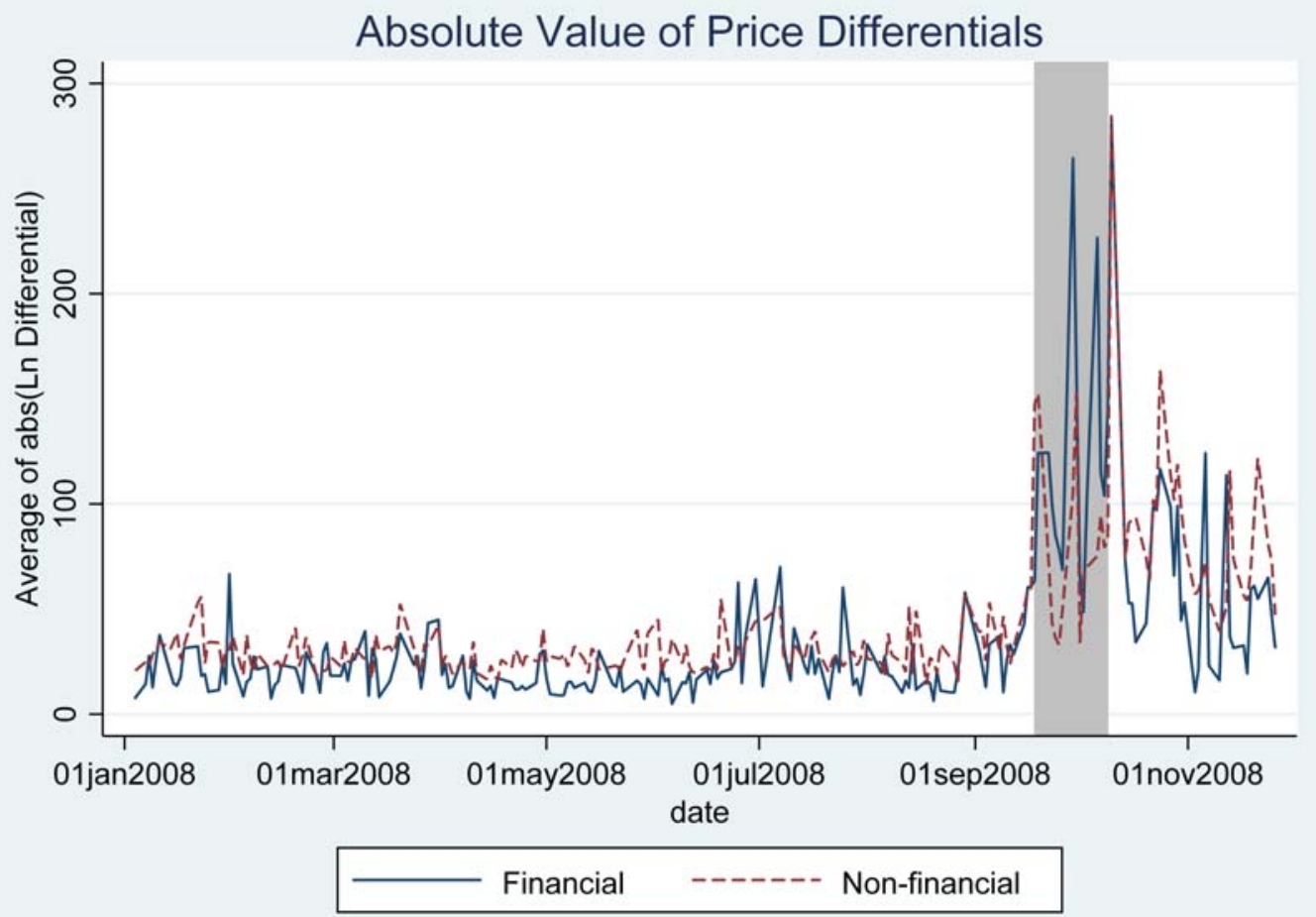


Figure 4: Relative Bid-Ask Spreads of Financial and Non-Financial Stocks

\section{Relative Bid-Ask Spreads}
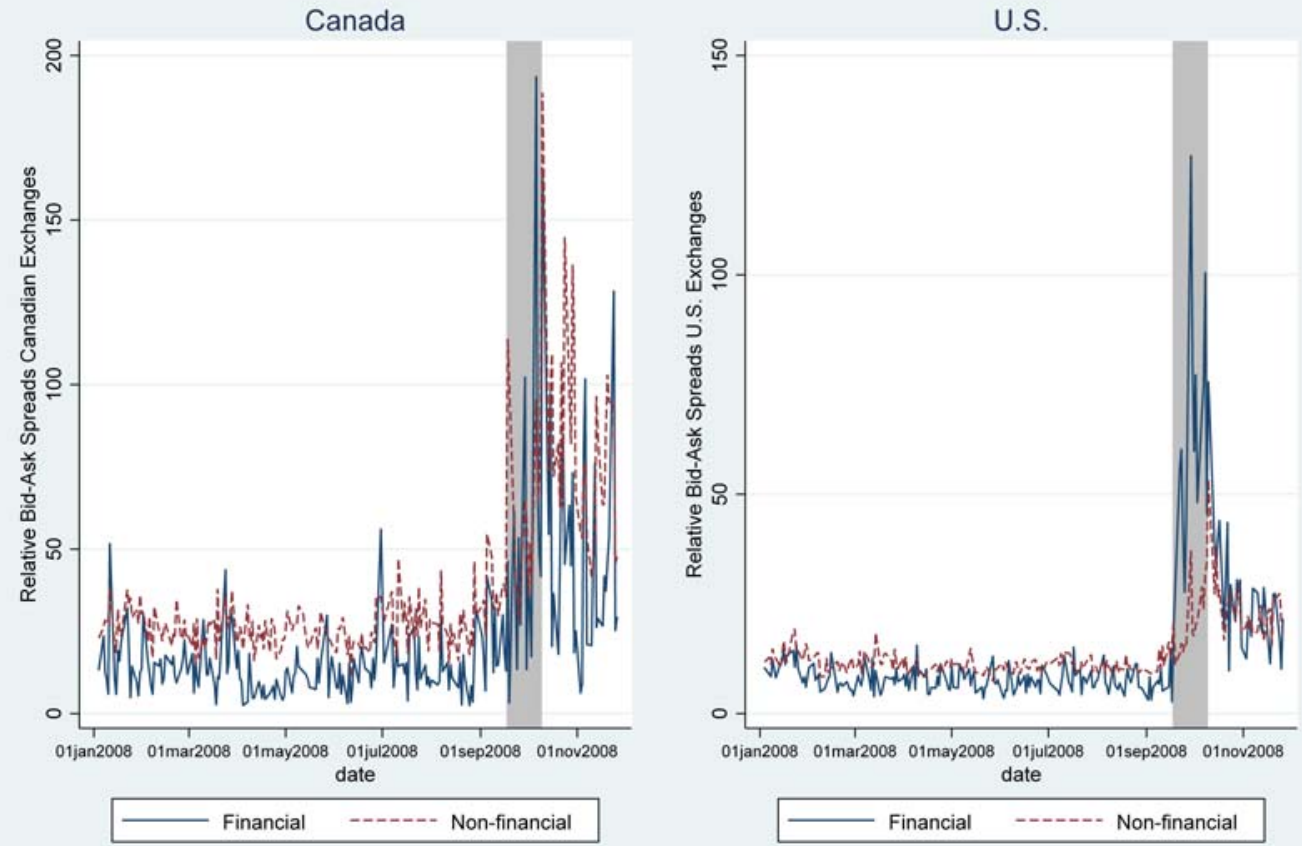
Figure 5: Volume of Financial and Non-Financial Stocks
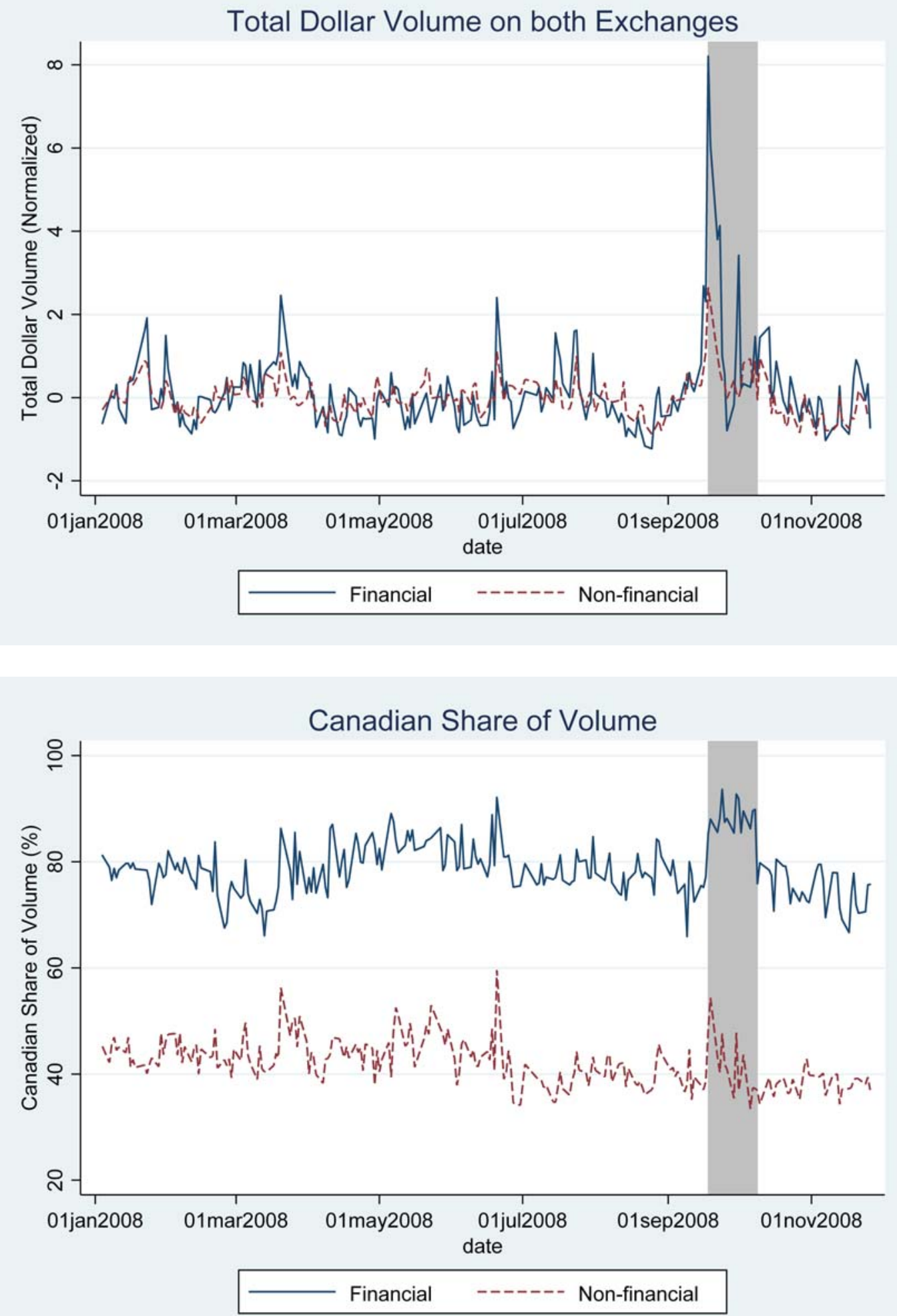
Figure 6: Short Interest of Financial and Non-Financial Stocks

\section{Proportion of Shares Shorted}
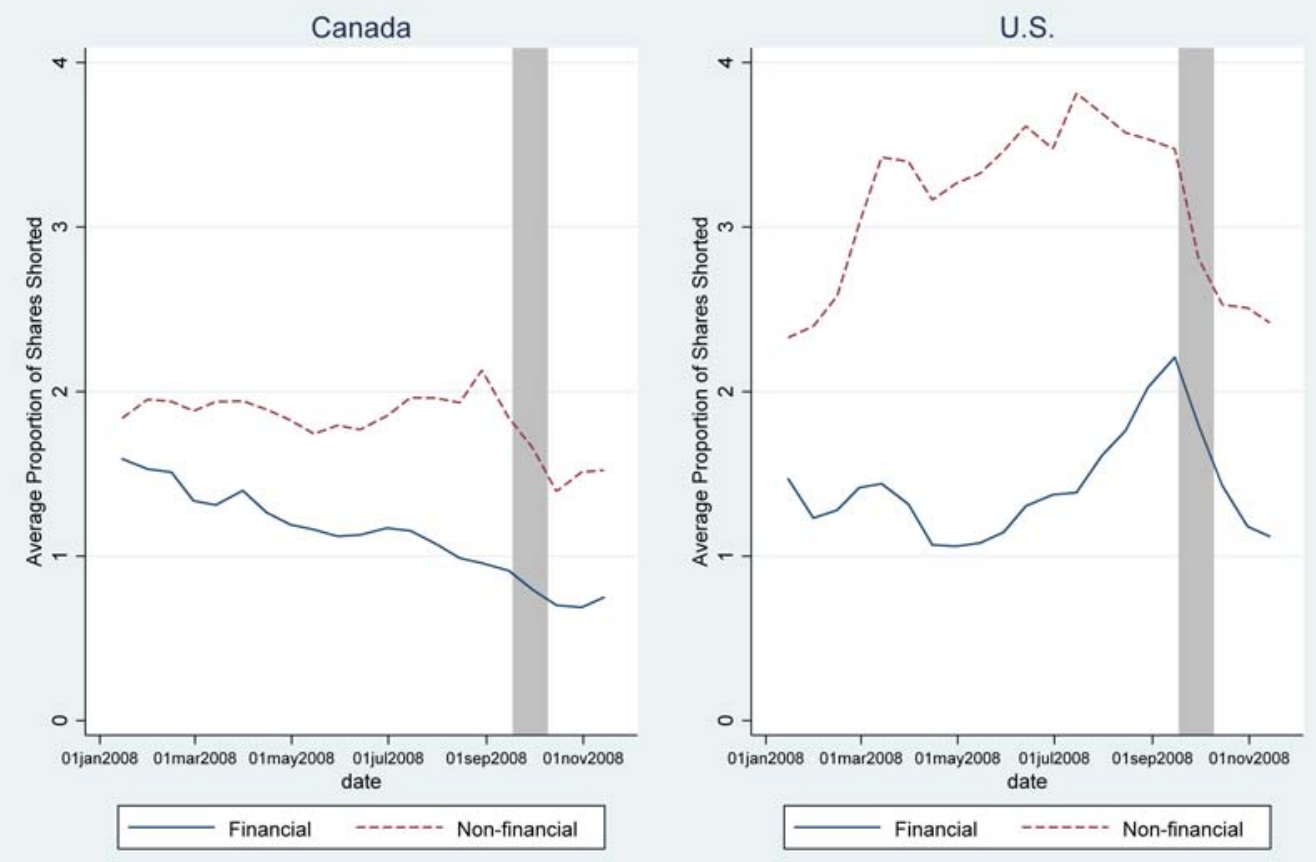